\title{
Genus Profundiconus Kuroda, 1956 (Gastropoda, Conoidea): Morphological and molecular studies, with the description of five new species from the Solomon Islands and New Caledonia
}

\author{
Manuel J. TENORIO ${ }^{1, *}$ \& Magalie CASTELIN ${ }^{2}$ \\ ${ }^{1}$ Dept. CMIM y Química Inorgánica - Instituto de Biomoléculas (INBIO), Facultad de Ciencias, \\ Torre Norte, $1^{a}$ Planta, Universidad de Cadiz, 11510 Puerto Real, Cadiz, Spain. \\ ${ }^{2}$ Fisheries and Oceans Canada, Pacific Biological Station, 3190 Hammond Bay Road, \\ Nanaimo BC V9T 6N7, Canada. \\ "Corresponding author: manuel.tenorio@uca.es \\ ${ }^{2}$ E-mail: magalie.castelin@gmail.com \\ ${ }^{1}$ urn:lsid:zoobank.org:author:24B3DC9A-3E34-4165-A450-A8E86B0D1231 \\ ${ }^{2}$ urn:lsid:zoobank.org:author:9464EC90-738D-4795-AAD2-9C6D0FA2F29D
}

\begin{abstract}
The genus Profundiconus Kuroda, 1956 is reviewed. The morphological characters of the shell, radular tooth and internal anatomy of species in Profundiconus are discussed. In particular, we studied Profundiconus material collected by dredging in deep water during different scientific campaigns carried out in the Solomon Islands, Madagascar, Papua New Guinea and New Caledonia. We reconstructed a phylogeny of 55 individuals based on partial mitochondrial cox 1 gene sequences. The phylogeny shows several clades containing individuals that do not match any of the known species of Profundiconus based on their shell and radular morphologies, and are introduced here as five new species: Profundiconus maribelae sp. nov. from the Solomon Islands; $P$. virginiae sp. nov. from Chesterfield Plateau (New Caledonia); P. barazeri sp. nov. from Chesterfield Plateau and the Grand Passage area (New Caledonia); P. puillandrei sp. nov. from Norfolk Ridge (New Caledonia), Kermadec Ridge (New Zealand) and possibly Balut Island (Philippines); and P. neocaledonicus sp. nov. from New Caledonia. Furthermore, Profundiconus teramachii forma neotorquatus (da Motta, 1984) is raised to specific status as P. neotorquatus (da Motta, 1984).
\end{abstract}

Keywords. Mitochondrial coxl gene, Conoidea, Profundiconus, deep-water species, Indo-West Pacific.

Tenorio M.J. \& Castelin M. 2016. Genus Profundiconus Kuroda, 1956 (Gastropoda, Conoidea): Morphological and molecular studies, with the description of five new species from the Solomon Islands and New Caledonia. European Journal of Taxonomy 173: 1-45. http:/dx.doi.org/10.5852/ejt.2016.173

\section{Introduction}

Kuroda (1956) introduced Profundiconus as a subgenus of Chelyconus Mörch, 1852, a member of the family Conidae Fleming, 1822. Chelyconus (?) (Profundiconus) profundorum Kuroda, 1956 [sic] (Fig. 1A) was originally designated as the type species. Profundiconus included simply coloured, 
deep-water species of cone snails of a rather large size, but with an extremely thin and elongated shell (Fig. 1). The presence of a rather large operculum with serrated outer margin was considered characteristic of the genus (Tucker \& McLean 1993; Tucker \& Tenorio 2009). The periostracum was referred to as "rather thickish, somewhat sericeous and very slightly laminated, of olivaceous colouration". In the same publication, Kuroda also described another large deep-water cone, Asprella teramachii Kuroda, 1956 (Fig. 1B), which he placed with a question mark in the subgenus Endemoconus Iredale, 1931. This species was at a later date considered as the type for the subgenus Lizaconus da Motta, 1991, within the genus Leptoconus Swainson, 1849.

In their Manual of the Living Conidae, Röckel et al. (1995a) treated all species of cone snails as members of one single genus Conus Linnaeus, 1758 within the family Conidae. Alternatively, Tucker \& Tenorio (2009) proposed a new classification for the recent and fossil cone snails based upon shell and radula morphologies and available molecular data. This classification, which was recently revised and updated in Tucker \& Tenorio (2013), divides the Holocene cone snails into three families with more than 100 genera. Recently, a large-scale molecular phylogeny including 320 out of the 761 recognized valid species of cone snails was reported (Puillandre et al. 2014). The phylogenetic analysis was based on three mitochondrial genes, and revealed four main highly divergent clades. Three of them correspond to reported lineages: one containing only the species Californiconus californicus (Reeve, 1844); another is the so called "Small Major Clade" sensu Duda \& Kohn (2005), roughly equivalent to the Conilithinae sensu Tucker \& Tenorio (2009), and the third one is the so called "Large Major Clade" sensu Duda \& Kohn (2005), roughly equivalent to the Conidae sensu Tucker \& Tenorio (2009). A fourth main clade was found, which included individuals of a number of deep-water Indo-Pacific species belonging to the genus Profundiconus sensu Tucker \& Tenorio (2009). In the subsequent classification of Conidae proposed by Puillandre et al. (2015), based on the molecular phylogeny, generic ranks were given to the four main clades, namely Conus, Conasprella Thiele, 1929, Californiconus Tucker \& Tenorio, 2009 and Profundiconus, respectively. According to the reconstructed phylogeny of Puillandre et al. (2014), Profundiconus is the sister-group to all the other cone snails, but this relationship was not statistically supported. The phylogeny is compatible both with the inclusion of Profundiconus in the family Conidae sensu Puillandre et al. (2014) or its placement in a separate family (e.g., Conilithidae, as suggested by Tucker \& Tenorio 2009).

According to Tucker \& Tenorio (2013), the genus Profundiconus includes 16 extant species, to which the recently described Profundiconus stahlschmidti Tenorio \& Tucker, 2014, Profundiconus tarava (Rabil-

Fig. 1. [opposite page] A. Profundiconus profundorum (Kuroda, 1956) (MJT coll., Okezoko, Kochi Prefecture, Japan, $350 \mathrm{~m}$ ), $75.0 \mathrm{~mm}$. B. Profundiconus teramachii (Kuroda, 1956) (MJT coll., South China Sea, trawled in $400 \mathrm{~m}$ ), $111.3 \mathrm{~mm}$. C. Profundiconus neotorquatus (da Motta, 1984) (MJT coll., NW coast of Madagascar, dredged in 600-800 m), $78.4 \mathrm{~mm}$. D. Profundiconus smirnoides Tenorio, 2015 (holotype, MNHN IM-2009-18220, off Ile des Pins, New Caledonia, 480-500 m), 71.8 mm. E. Conilithes antidiluvianus (Bruguière, 1792), Upper Pliocene, Piacenzian Stage (MJT coll., Pedrera Anna, Molins de Rey, Barcelona, Spain), 35.3 mm. F. Profundiconus emersoni (Hanna, 1963) (LACM 146906, off Isla Santa Maria (Charles), Galápagos Is., Ecuador, $310 \mathrm{~m}$ ), $33.7 \mathrm{~mm}$. G. Profundiconus tuberculosus (Tomlin, 1937) (MJT coll., Miura, Sagami Bay, Kanagawa Prefecture, Japan, 100 m), $13.7 \mathrm{~mm}$. H. Profundiconus loyaltiensis (Röckel \& Moolenbeek, 1995) (holotype, MNHN IM-20002545, Ride des Loyauté, New Caledonia, $480 \mathrm{~m}$ ), $21.8 \mathrm{~mm}$. I. Profundiconus vaubani (Röckel \& Moolenbeek, 1995) (holotype, MNHN IM-2000-3455, Norfolk Ridge, New Caledonia, $435 \mathrm{~m}$ ), $25.8 \mathrm{~mm}$. J. Profundiconus kanakinus (Richard, 1983) (MNHN, South New Caledonia, 410-440 m), $19.5 \mathrm{~mm}$. K. Profundiconus cakobaui Moolenbeek et al., 2008 (holotype, MNHN IM-2000-21030, Somo-somo Strait, South of Vanua Levu, Fiji, 426-487 m), 18.9 mm. L. Profundiconus profundorum (Kuroda, 1956) (MJT coll., South China Sea, trawled in 500-600 m), $109.9 \mathrm{~mm}$. Scale bars $=10 \mathrm{~mm}$. 


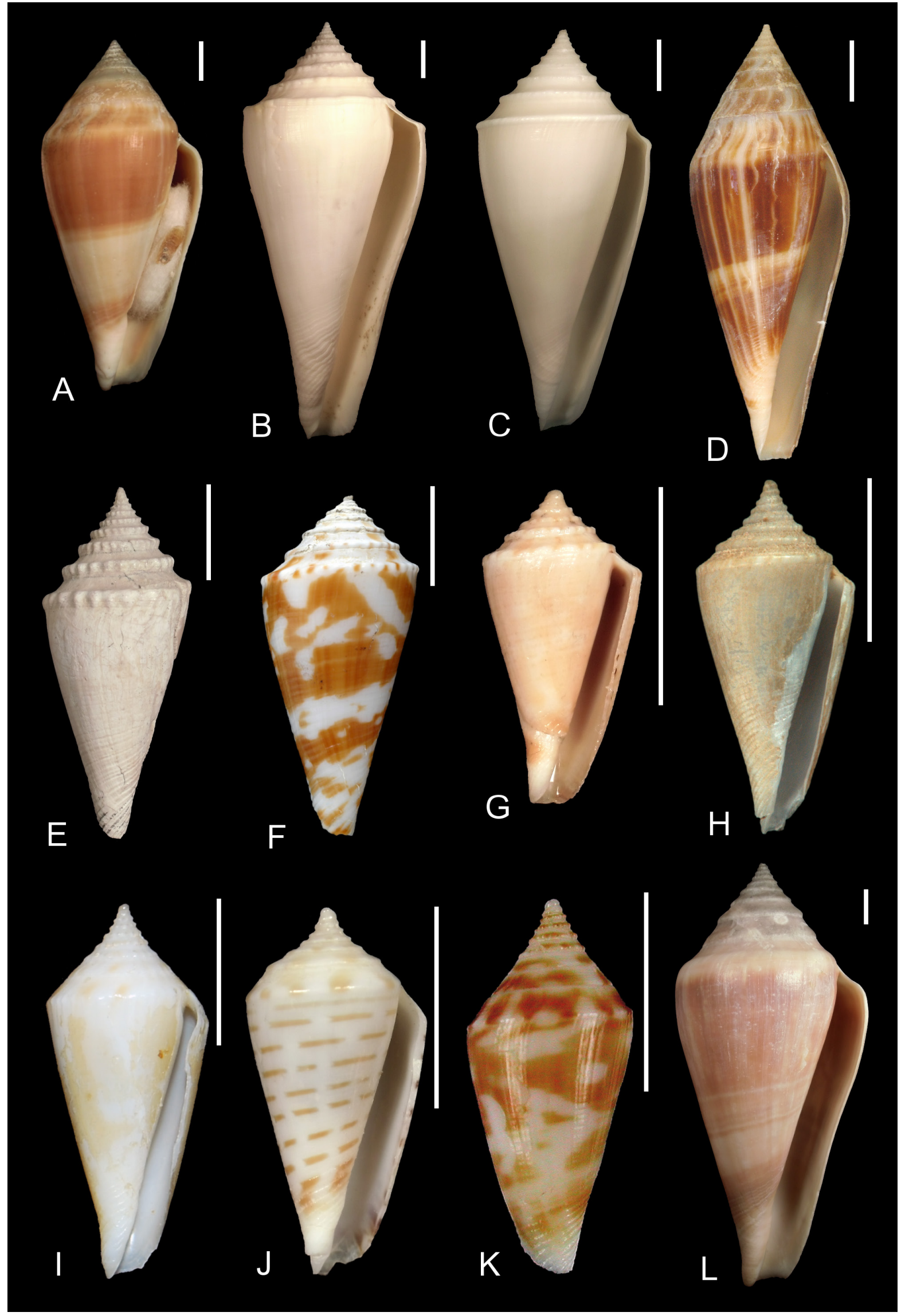


ler \& Richard, 2014), Profundiconus zardoyai Tenorio, 2015 and Profundiconus smirnoides Tenorio, 2015 (Fig. 1D) must be added. As of November 2015, WoRMS lists 24 records under Profundiconus, including one fossil species, Profundiconus hennigi Hendricks, 2015, of doubtful assignment to this genus (WoRMS Editorial Board 2015). Two of the listed records, Conus (Profundiconus) nigrostriatus Kosuge, 1979 and Profundiconus soyomaruae Okutani, 1964, are junior subjective synonyms of Profundiconus lani (Crandall, 1979) and P. profundorum respectively (Röckel et al. 1995a; Tucker \& Tenorio 2013). Two of the other listed taxa are now ascribed to other genera: Profundiconus luciae (Moolenbeek, 1984) has been placed by Tucker \& Tenorio (2013) in the genus Kurodaconus Shikama \& Habe, 1968 (considered a synonym of Turriconus Shikama \& Habe, 1968 by Puillandre et al. 2015). A study of the radular morphology indicated that Profundiconus darkini (Röckel, Korn \& Richard, 1993) is actually not a Profundiconus but a typical Conidae, and it has tentatively been placed in the genus Embrikena Iredale, 1937 (Tucker \& Tenorio 2013). Moreover, recent molecular studies suggest that this species belongs to the same clade as Kurodaconus luciae (Puillandre, pers. comm.). Therefore, it is feasible to assume that darkini is also a member of the genus Kurodaconus.

Apart from the known extant species, the genus Profundiconus has a long fossil record ranging from the Cretaceous (Profundiconus primitivus (Collignon, 1949)) to the Pliocene (i.e., Profundiconus yanuyanuensis (Ladd, 1945)). None of the extant species of Profundiconus have been reported as fossils (Tucker \& Tenorio 2009). The extant species included in the genus Profundiconus occur in the IndoPacific region except for P. emersoni (Hanna, 1963) (Fig. 1F), which occurs in the East Pacific region (Tucker \& McLean 1993; Tenorio et al. 2012). However, the inclusion of this species in Profundiconus is only provisional (Tenorio et al. 2012). The fossil species are known from the Indo-Pacific region and North America.

As their name indicates, species of Profundiconus normally live in deep to very deep water. P. teramachii has been found at depths of $1134 \mathrm{~m}$ (dead) and $977 \mathrm{~m}$ (live) (von Martens 1901). However, not all Profundiconus are restricted to deep water: Röckel et al. (1995a) reported 20-300 m for P. ikedai (Ninomiya, 1987) and 75-560 $\mathrm{m}$ for $P$. lani. The value of $20 \mathrm{~m}$ corresponding to the minimal depth for $P$. ikedai seems too shallow in spite of being quoted in the original description for this species. Okutani (2000) corrected these depth ranges to 250-300 $\mathrm{m}$ for P. ikedai and 50-560 m for P. lani. In general, the deep-sea habitat makes these species difficult to sample. The most commonly collected one is P. teramachii (Fig. 1B), which surfaces in the nets of deep-water fishing trawlers. Most of the other species are rare in collections. However, species of Profundiconus are not uncommon among the material resulting from dredging carried out by research vessels in deep waters. In this context, the Muséum national d'Histoire naturelle (MNHN) has been carrying out a series of oceanographic expeditions in the deep waters surrounding New Caledonia and beyond since 1980 (Bouchet et al. 2008). Many of those research cruises were surveying the seamounts of the Norfolk Ridge (Castelin et al. 2011), dredging and trawling from $80 \mathrm{~m}$ to a depth of $3000 \mathrm{~m}$. Other areas covered have included the Plateau des Chesterfield and the Grand Passage area. More recently, deep-water surveys have been carried out in the Fiji Islands, Philippines, Vanuatu, Madagascar, Papua New Guinea and other locations, with more missions in preparation. These research cruises produced large lots of deep-water cone snails, both in live and dead condition, with exact depth and locality data. Species of the genus Profundiconus are well represented, and their study by an international network of taxonomists has already produced new species (Tenorio 2015a, 2015b; Rabiller \& Richard 2014; Moolenbeek et al. 2008; Röckel et al. 1995b).

Here, we reconstruct the phylogeny of the genus Profundiconus, including a total of 55 individuals for which a fragment of the coxl gene was sequenced. The phylogeny, in conjunction with comparative analyses of shell and radula characters, provides useful insights into the taxonomy of Profundiconus. The phylogeny shows several clades containing individuals that do not match any of the known species 
of Profundiconus according to their shell and radular morphologies, and they are introduced here as new species.

\section{Material and methods}

Most of the material studied here was previously deposited in institutional repositories. Descriptions and measurements are based on shells oriented in the traditional way; spire up with the aperture facing the viewer. The taxonomy used in the present work follows Tucker \& Tenorio (2009) with the updates and modifications included in Tucker \& Tenorio (2013). Specimens were collected by dredging in deep water during different campaigns carried out by the MNHN in New Caledonia and the Solomon Islands, most of them aboard the R/V Alis between 1985 and 2008, at depth ranges of 270 to $1100 \mathrm{~m}$. Some specimens were taken off Curtis Island, Kermadec Ridge and west of northern New Zealand from a depth of 900-1100 $\mathrm{m}$ by R/V Tangaroa during a dredging campaign by the New Zealand Oceanographic Institute in 1979. Distribution maps were generated using GeoMapApp (http://www.geomapapp.org) with the general bathymetric map of the oceans as the default basemap.

We describe shell morphology using the terminology established in Röckel et al. (1995a). We also used their procedure for counting the number of protoconch whorls. For morphometric comparisons, adult shells randomly selected among available specimens in the collections of the MNHN and other sources (private collections) were measured with a digital caliper and the measurements rounded to 0.1 millimeter. All the measurements are in a spreadsheet, deposited as electronic supporting information (Appendix). For comparisons of shell morphometry, we performed analyses of the covariance (ANCOVA) for different shell parameters, namely maximum diameter (MD), height of the maximum diameter (HMD) and spire height $(\mathrm{SH})$, using species hypotheses as factor and shell length $\left(\mathrm{S}_{\mathrm{L}}\right)$ as covariate. Additionally, we statistically compared the mean values of $S_{L}$ using t- and U-tests. Statistical tests were carried out using STATGRAPHICS 5.1 or PAST3 (Hammer et al. 2001) once all the measurement sets passed the normality tests.

We used the terminology for radular morphology of Tucker \& Tenorio (2009) and the abbreviations in Kohn et al. (1999). The number of individuals for which the entire radula was examined is indicated in the description of each new taxon. Specimens of shells containing the dried animal inside were digested in concentrated aqueous $\mathrm{KOH}$ for $24 \mathrm{~h}$. The contents were flushed out of the shell by injecting distilled water through the aperture of the shell by means of a syringe with an incurved needle. The resulting mixture was then placed in a Petri dish and examined with the binocular microscope. The entire radula was removed with fine tweezers and rinsed with distilled water, then mounted on a slide using Aquatex (Merck) Mounting Medium and examined under the optical microscope. Photos were obtained with a CCD camera attached to the microscope. Samples of individual radular teeth for scanning electron microscopy (SEM) were allowed to dry in the air upon rinsing with distilled water and then mounted on stubs covered with double-sided carbon tape. SEM studies were carried out at the MNCN-CSIC on a FEI Inspect scanning electron microscope, equipped with a secondary and retro-dispersed electron detector, and an Oxford Instruments analytical-INCA integrated analysis system.

Forty-one partial DNA sequences of the mitochondrial coxl gene (Folmer et al. 1994) were extracted from GenBank (from the study of Puillandre et al. 2014; GenBank accession numbers in Table 1). This corresponded to a selection of the DNA sequences of the targeted species of Profundiconus as defined by Tucker \& Tenorio (2013), which includes members of the "teramachii/smirna/aff. profundorum/n. sp. g" complex mentioned in Puillandre et al. (2014). An additional set of 14 coxl sequences corresponding to Profundiconus species were kindly supplied by Dr. Nicolas Puillandre (submitted to GenBank and BOLD) and included in the present study, increasing the number to 55 specimens. Within Conoidea, the sister group of the cone snails is Borsoniidae (Tucker \& Tenorio 2009: fig. 16; Puillandre et al. 2011, 2014). Consequently, we included in our analyses one member of the family Borsoniidae: Bathytoma 


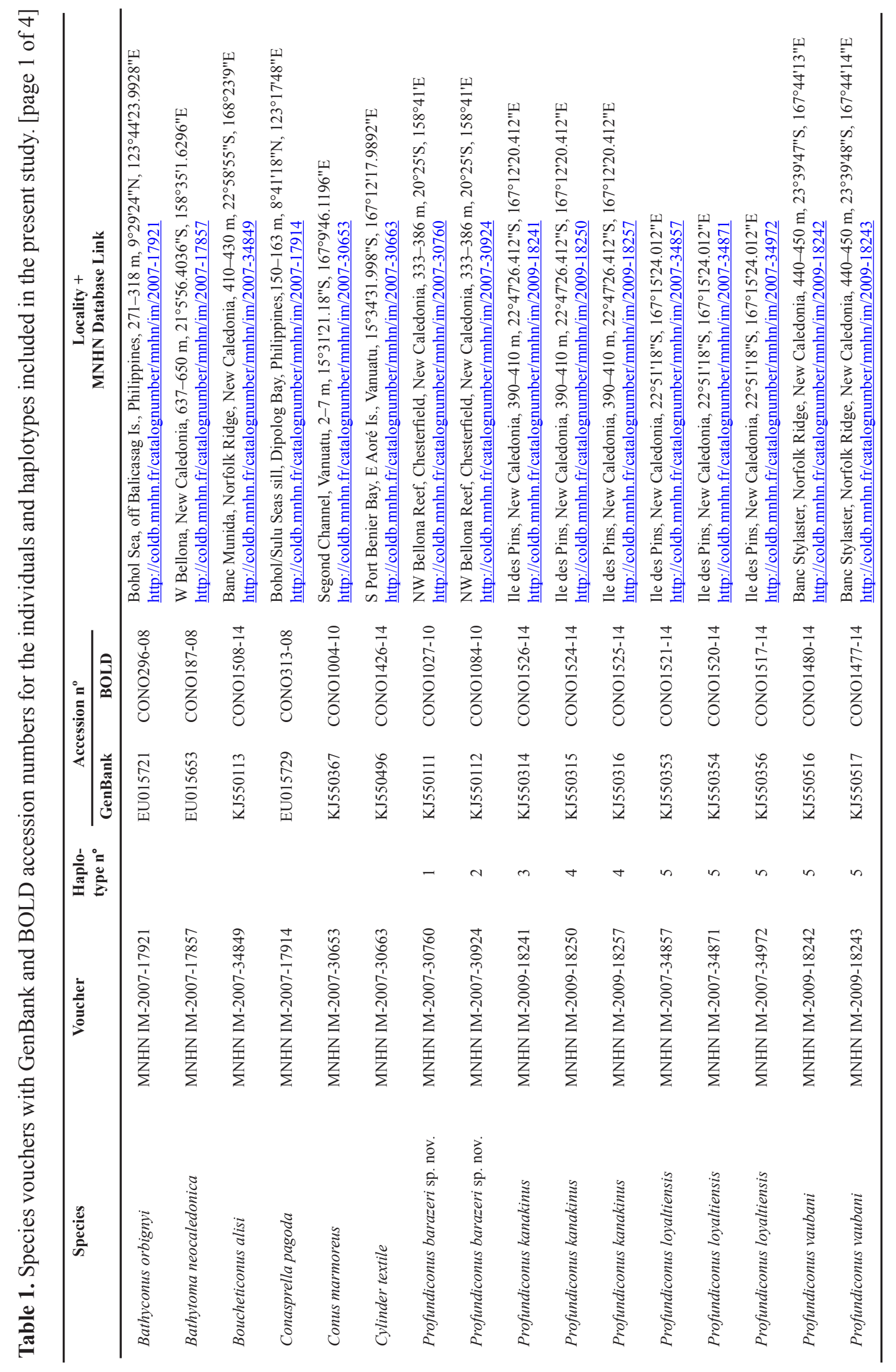




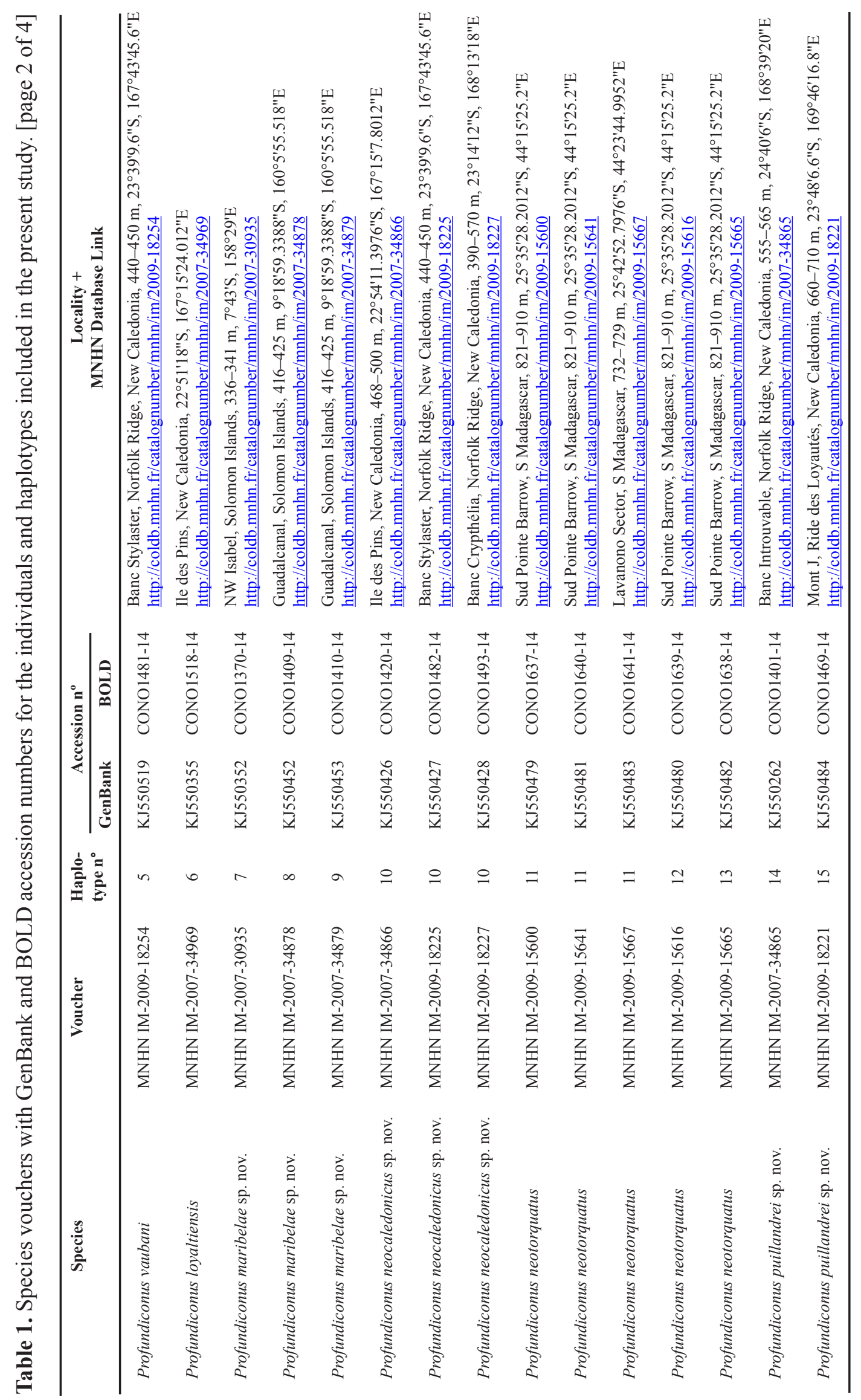




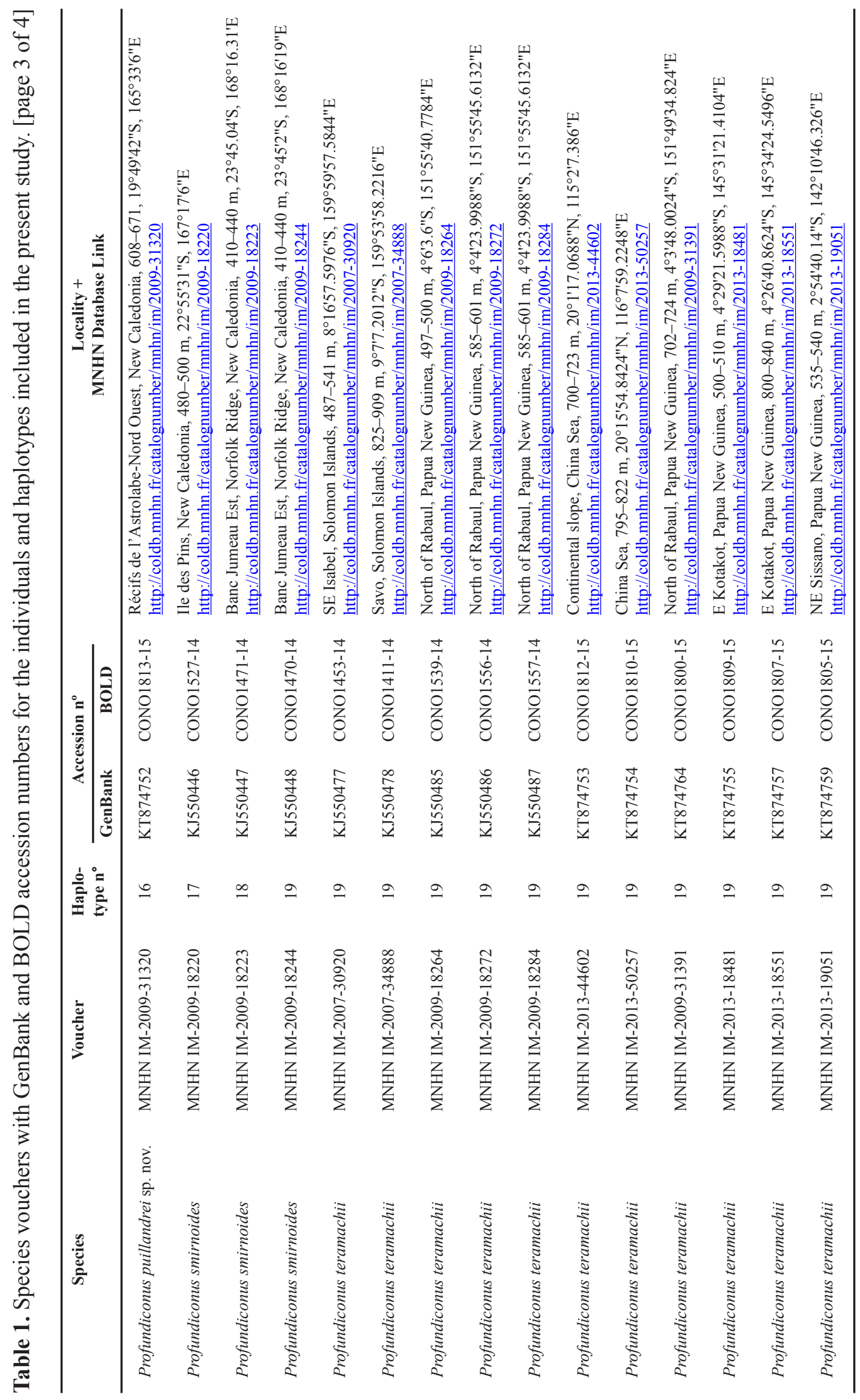




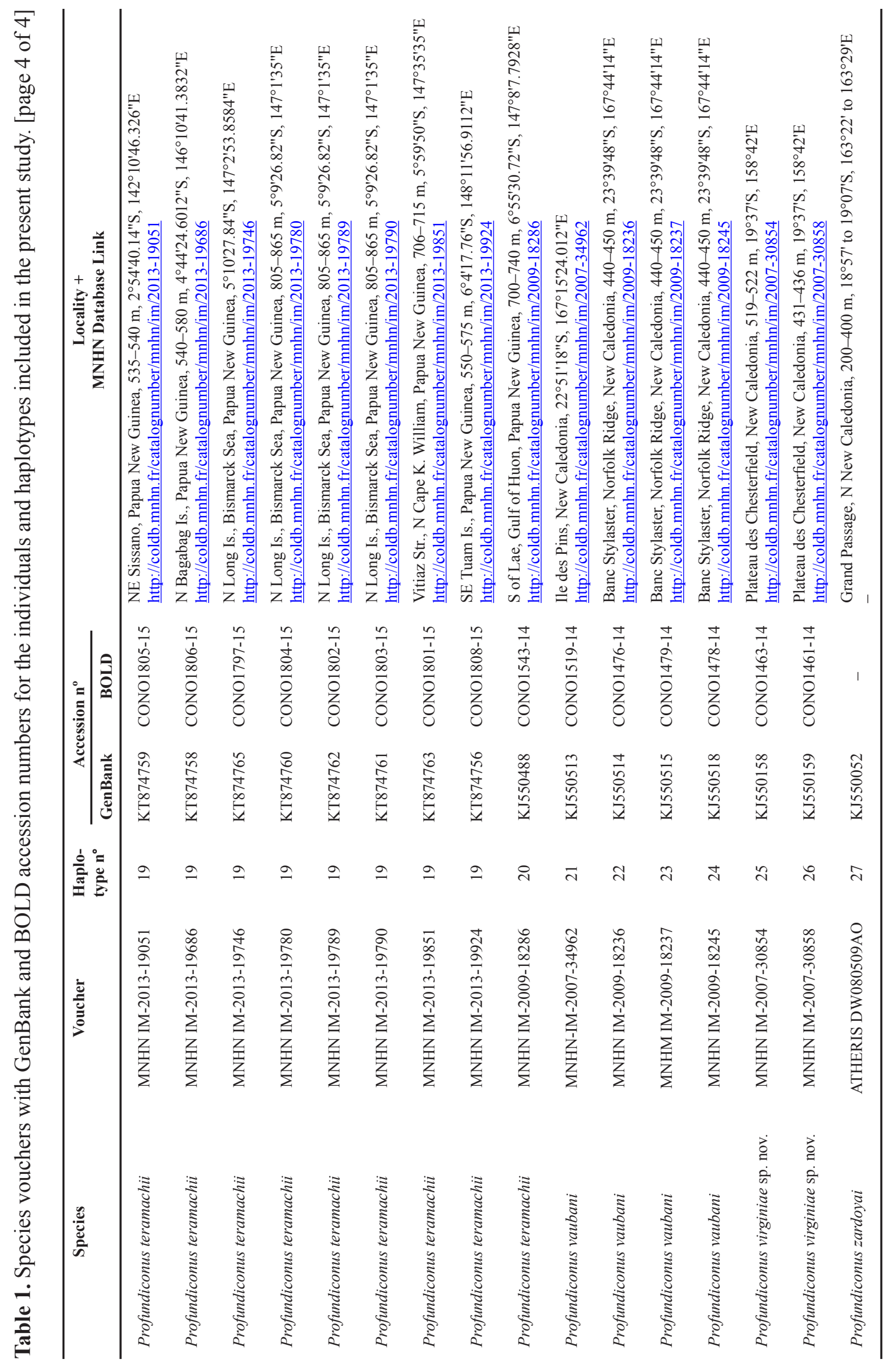


neocaledonica Puillandre, Sysoev, Olivera, Couloux \& Bouchet, 2010 was selected as the most external outgroup of the targeted species complex. In addition, sequences from GenBank of other species of cone snails from two different clades, namely Conus marmoreus Linnaeus, 1758, Cylinder textile (Linnaeus, 1758), Bathyconus orbigny (Audoin, 1831), Conasprella pagoda (Kiener, 1847) and Boucheticonus alisi (Moolenbeek, Röckel \& Richard, 1995), were selected to form a closer outgroup in order to provide a broader phylogenetic context for the species complex that we were interested in.

The coxl gene sequences were translated into amino-acids using MEGA v. 4.0 (Tamura et al. 2007) and the invertebrate mitochondrial genetic code to check for stop codons. DNA sequences were aligned using the MUSCLE Server (Edgar 2004). The accuracy of DNA sequence alignment was confirmed by eye. Identical DNA sequences were identified using DnaSP v. 5 (Librado \& Rozas 2009) and excluded from posterior analyses. The best-fit nucleotide substitution model $(\mathrm{HKY}+\mathrm{I}+\mathrm{G})$ for the cox 1 dataset was determined using JModeltest 2 (Guindon \& Gascuel 2003; Darriba et al. 2012) and the Bayesian Information Criterion (BIC; Posada \& Buckley 2004). A maximum likelihood (ML) tree was built using RAxML HPC2 (Stamatakis 2006) on Teragrid v. 7.2.7, implemented in the Cyber Infrastructure for Phylogenetic Research (CIPRES) portal version 3.1 (http://www.phylo.org/portal2). The best-scoring ML tree was estimated from 100 independent searches, each starting from distinct random trees. Robustness of nodes was assessed using the rapid bootstrapping algorithm (1000 replicates) (Felsenstein 1985; Stamatakis et al. 2008). Bayesian analyses (BA) were performed running two parallel analyses in MrBayes (Huelsenbeck \& Ronquist 2001), each consisting of four Markov chains of 5000000 generations, each with a sampling frequency of 1 tree each 100 generations. The number of swaps was set to 5 , and the chain temperature at 0.05 . Convergence and mixing of the chains of each analysis was evaluated using Tracer v. 1.4.1 (Rambaud \& Drummond 2007) to check that effective sample size (ESS) values were all greater than 200 . A consensus tree was then calculated after omitting the first $25 \%$ of trees as burn-in. We considered a clade to be 'moderately supported' if it had a bootstrap support value (BP) between 75 and $89 \%$ and posterior probability (PP) between 0.95 and 0.97 , and 'highly supported' when $\mathrm{BP} \geq 90 \%$ and $\mathrm{PP} \geq 0.98$ (Fig. 2).

The following abbreviations are used for museums and institutions:

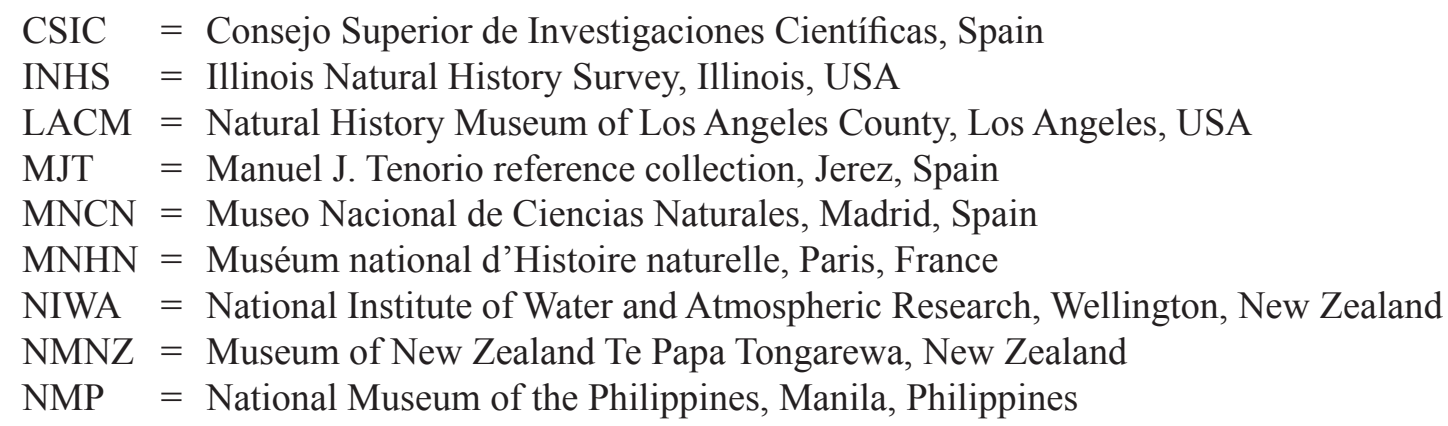

Abbreviations for shell morphometry:

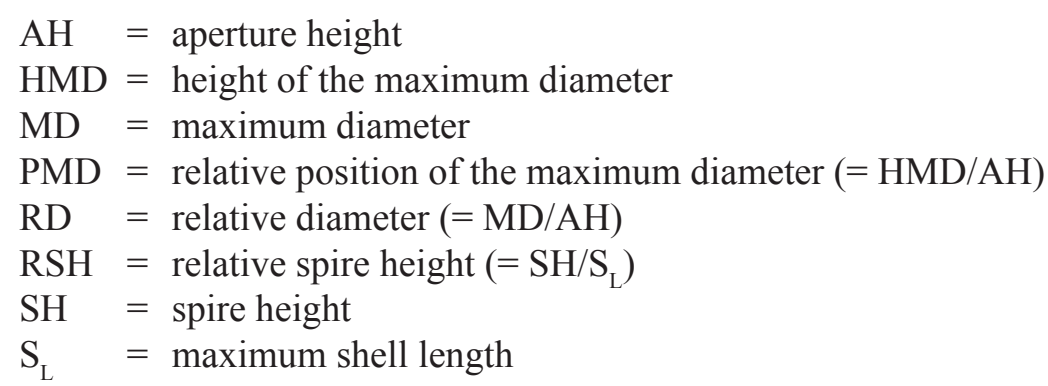


Abbreviations for radular morphometry:

$\mathrm{S}_{\mathrm{L}} / \mathrm{T}_{\mathrm{L}} \quad=$ shell length/radular tooth length

$\mathrm{T}_{\mathrm{L}} / \mathrm{AP}_{\mathrm{L}} \quad=$ radular tooth length/anterior portion length

$100 \mathrm{~B}_{\mathrm{L}} / \mathrm{AP}_{\mathrm{L}}=100 \times$ blade length/anterior portion length

$100 \mathrm{AO}_{\mathrm{L}} / \mathrm{AP}_{\mathrm{L}}=100 \times$ adapical opening length/anterior portion length

\section{Results}

Class Gastropoda Cuvier, 1795

Subclass Caenogastropoda Cox, 1960

Order Neogastropoda Wenz, 1938

Superfamily Conoidea Fleming, 1822

Family Conilithidae Tucker \& Tenorio, 2009

Genus Profundiconus Kuroda, 1956

Lizaconus da Motta, 1991 (type species: Asprella (Endemoconus?) teramachii Kuroda, 1956).

\section{Type species}

Chelyconus (?) (Profundiconus) profundorum Kuroda, 1956 (by original designation).

\section{Description}

SHELl CHARACTERS (Fig. 1). Conical to narrowly conical shell, usually thin, very small to very large in size; shoulders become rounded in outer whorls, although a ridge is present in some cases; a few cords present on early whorls and become numerous and smaller in outer whorls; nodules obsolete early; anal notch shallow; larval shell either paucispiral or multispiral; operculum large and serrate; periostracum smooth.

RAdUlar toотн (Fig. 2). Blade and barb present (may be poorly differentiated); blade pointed, moderate in length, up to half length of anterior section of tooth; serrations absent; adapical opening large; a structure that we will refer to as external cusp (non-homologue of a posterior blade) starting at base of adapical opening and extending towards waist; external cusp often laterally expanded and serrated, with several small denticles (Fig. 2C, F); external cusp may appear partially covered by rolled sheet, which conforms to anterior portion of tooth; barb, blade and external cusp arranged in three different planes, which form angle of $c .120^{\circ}$ between them; waist evident; characteristic fringe composed of closely spaced projections pointing towards apex present immediately below waist (Fig. 2C, F); anterior section of tooth shorter than posterior section; shaft fold present; slanted base with large basal spur.

Internal anatomy (Figs 4-5). The internal anatomy of Profundiconus tuberculosus (Tomlin, 1937) (Fig. 1G) has been studied in detail by Taki (1937), and can be considered representative for other members of the genus. Taki's work was reviewed by Röckel (1994). Some details of the external anatomy and radular apparatus of several other species of Profundiconus are presented in Rolán \& RaybaudiMassilia (1994). We hereby reproduce some of the figures from Taki (1937) (Figs 4-5) to illustrate the details of the internal anatomy in Profundiconus.

Taki (1937) remarked that the anatomical features of P. tuberculosus indicate in many aspects the ancestral nature of this species. The proboscis sheath (Fig. 3A: RS) has longitudinal folds on the inner side; the inner wall of the respiratory siphon (Fig. 3A-B: SI) is smooth, lacking the furrows or invaginations that have been reported in other species of cone snails; the osphradium (Fig. 3B: OS) is simple and not 
divided, with the small lobules arranged like feather banners on both sides of the longitudinal axis; there is only one salivary gland (Fig. 3B: SD), consisting of a multitude of small lobules.

The anterior lobe of the midgut gland (Fig. 4A: $\mathrm{L}_{1}, \mathrm{~L}_{2}$ ) has a bifurcated excretory duct. The male genitalia (Fig. 4B) have been described in detail. The organs that Bergh (1896) described as testes are considered to be the prostate in the opinion of Taki (1937). The testis consists of two lobes (Fig. 4B: HA, HP), which are spirally coiled and reach the tip of the spire. The prostate (Fig. 4B: PG) is separated into three parts (PGA, PGD, PGS), with irregular shallow grooves on its surface. Both cerebral ganglia (Fig. 4C: C) largely merge with each other and can be distinguished only by a slight constriction in the middle; the right parietal and right visceral nerves (Fig. 4C: PA, V) go together as a single nerve from the subintestinal (IN) ganglion. They separate only after a prolonged course.

\section{Geologic range}

Cretaceous to Recent.

\section{Geographic distribution}

The Holocene species included in the genus (Table 2) occur in the Indo-Pacific region, except for Profundiconus emersoni (Fig. 1F), which occurs in the East Pacific region. Extinct species are known from the Indo-Pacific region and North America (Tucker \& Tenorio 2009). For a listing of fossil species placed in the genus Profundiconus, see Tucker \& Tenorio (2009).

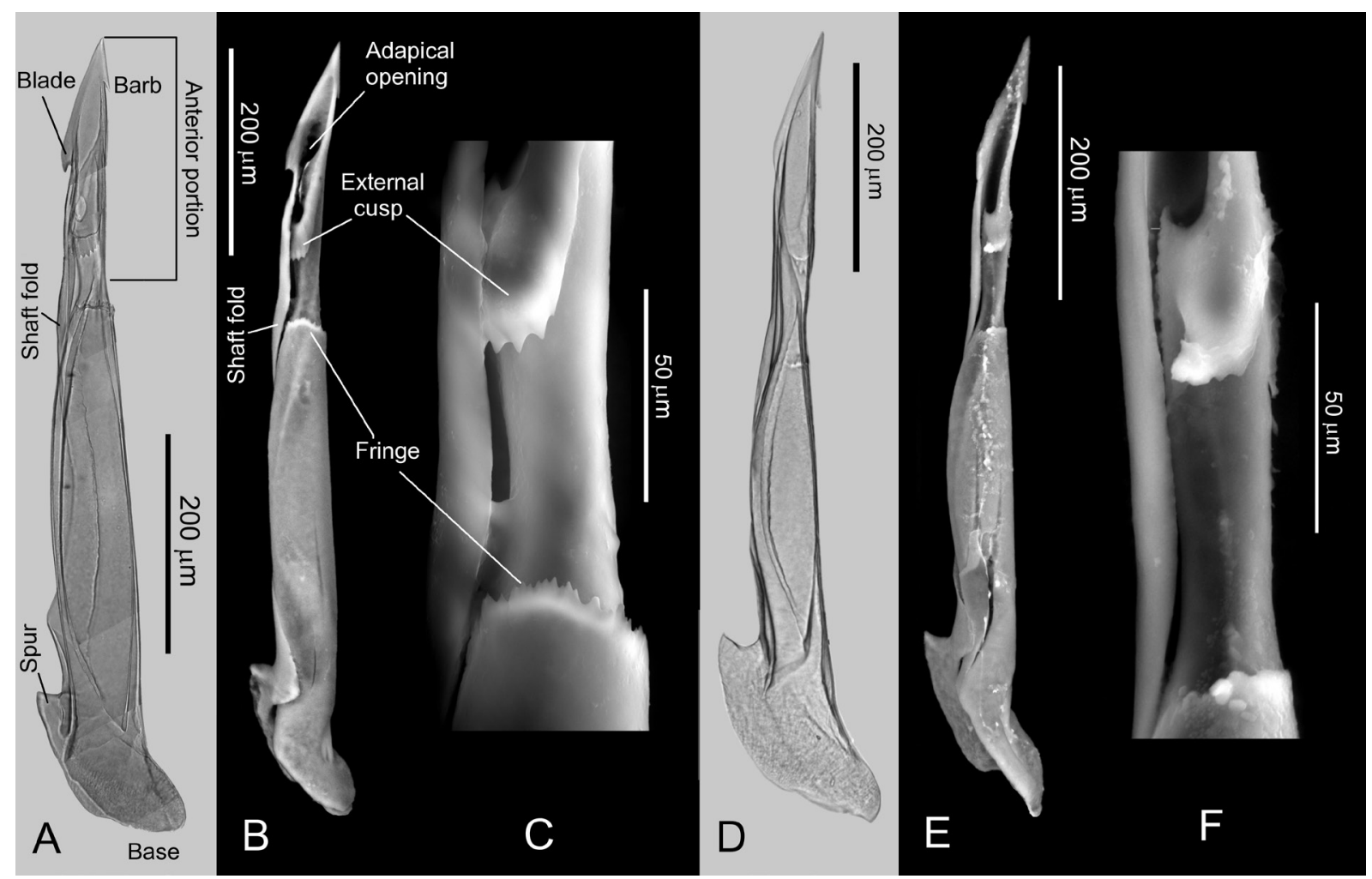

Fig. 2. - A-C. Radular teeth extracted from Profundiconus vaubani (Röckel \& Moolenbeek, 1995), with major parts and structures labelled. A. Optical photograph (MNHN, uncataloged, $\mathrm{S}_{\mathrm{L}} 20.6 \mathrm{~mm}$ ). B. SEM photograph (MNHN, uncataloged, $S_{L} 26.0 \mathrm{~mm}$ ). C. Enlargement of the middle section of B. D-F. Radular teeth extracted from Profundiconus teramachii (Kuroda, 1956). D. Optical photograph (MNHN IM-2013-44602, S 82.7 mm). E. SEM photograph (MNHN IM-2013-50257, S 76.7 mm). F. Enlargement of the middle section of $\mathrm{E}$. 

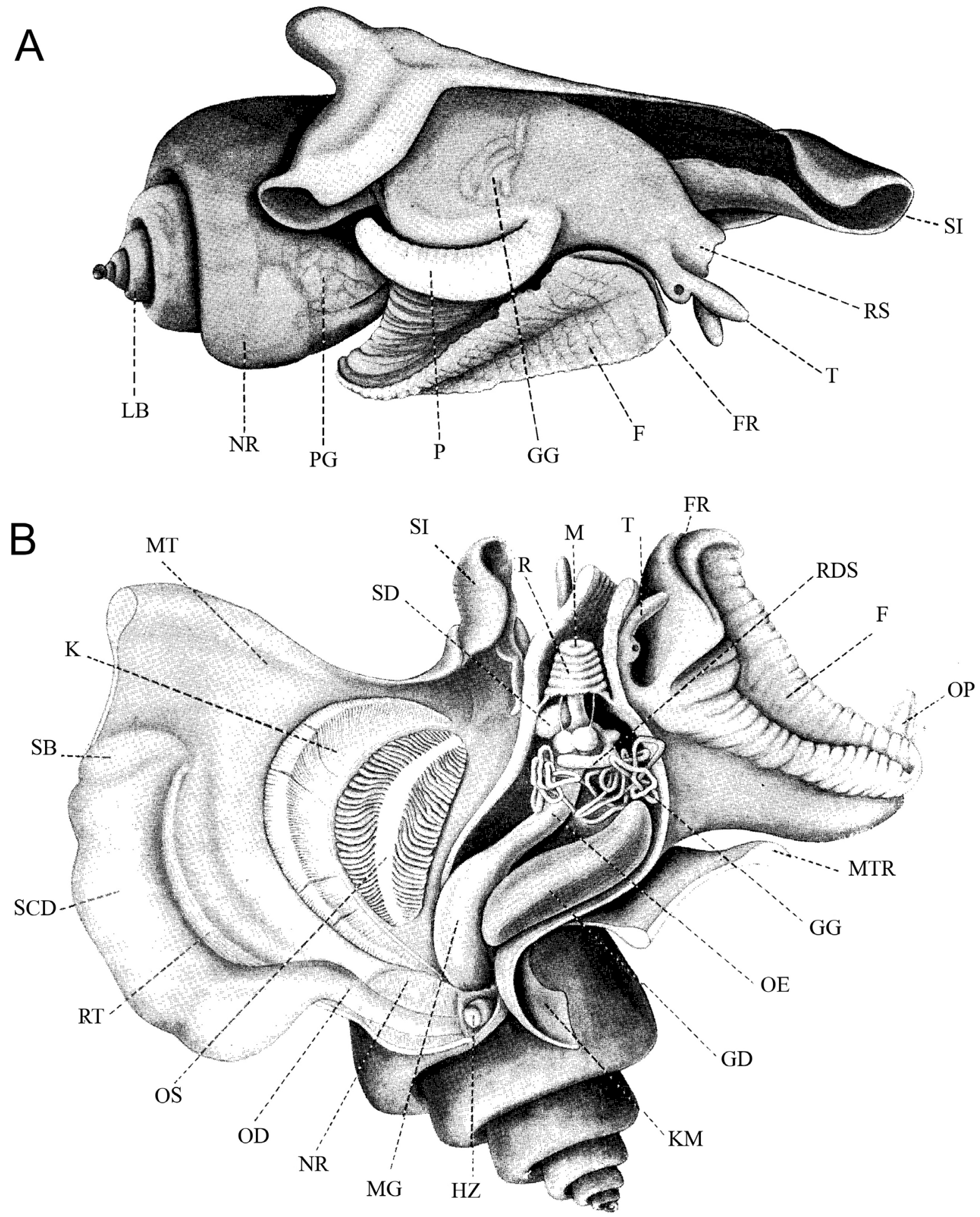

Fig. 3. Profundiconus tuberculosus (Tomlin, 1937) (reproduced from Taki 1937, with permission from the Zoological Society of Japan). A. External anatomy, male specimen. B. Internal anatomy. F = foot; $\mathrm{FR}=$ rostrum frontal lobe; $\mathrm{GD}=$ venom bulb; $\mathrm{GG}=$ venom duct; $\mathrm{HZ}=$ heart; $\mathrm{K}=$ gill; $\mathrm{LB}=$ middle gut; $\mathrm{M}=$ mouth $\mathrm{MG}=$ stomach; $\mathrm{MT}=$ mantle; $\mathrm{MTR}=$ mantle edge; $\mathrm{NR}=$ kidney; $\mathrm{OD}=$ oviduct $\mathrm{OE}=$ oesophagus; $\mathrm{OP}=$ operculum; $\mathrm{OS}=$ osphradium; $\mathrm{P}=$ penis; $\mathrm{PG}=$ prostate $\mathrm{R}=$ rostrum; $\mathrm{RDS}=$ radular sac; $\mathrm{RT}=$ rectum; $\mathrm{SB}=$ receptaculum seminis $; \mathrm{SCD}=$ mucous gland; $\mathrm{SD}=$ salivary gland; $\mathrm{SI}=$ siphon; $\mathrm{T}=$ tentacles. 

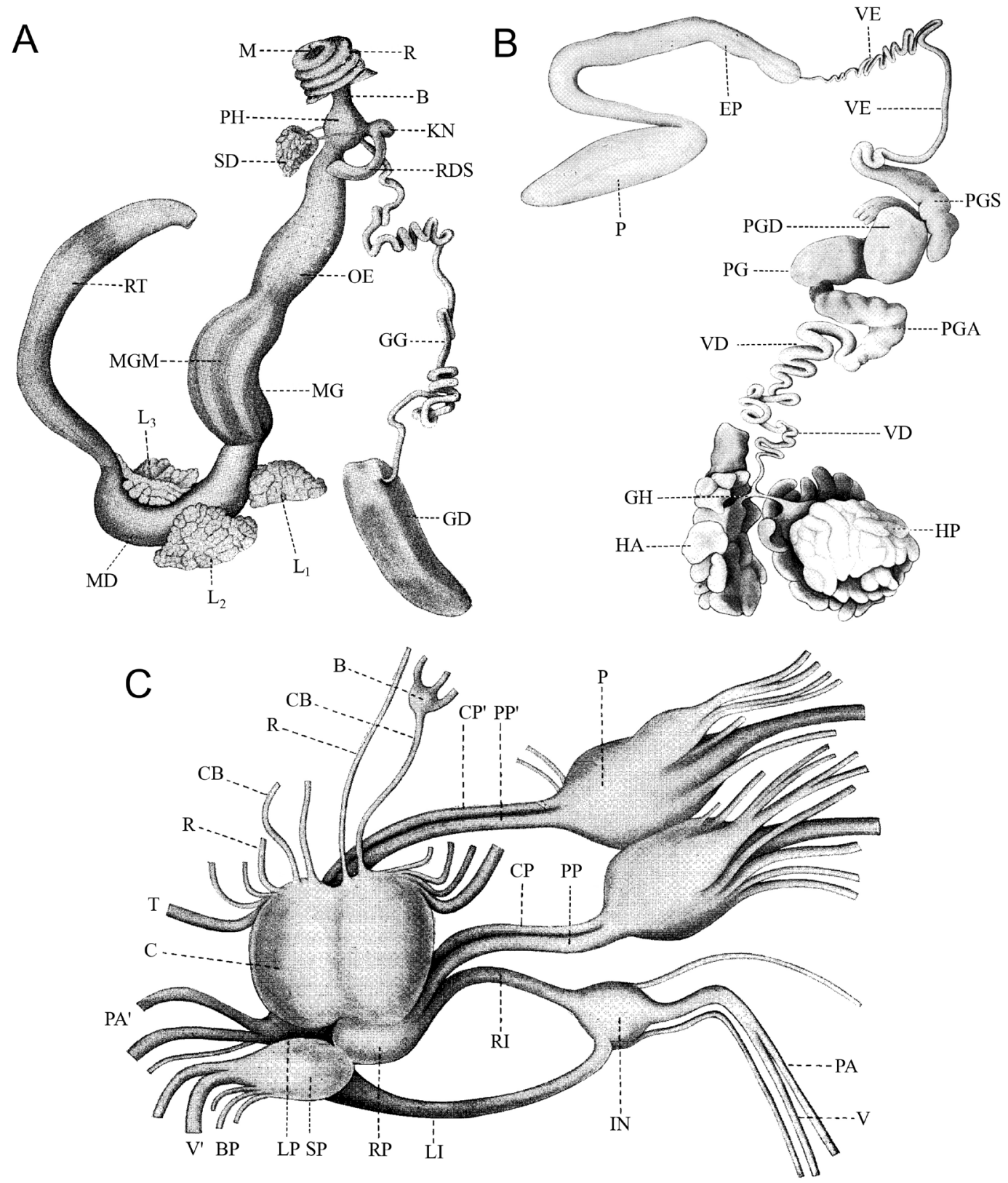

Fig. 4. Profundiconus tuberculosus (Tomlin, 1937) (reproduced from Taki 1937, with permission from the Zoological Society of Japan). A. Digestive apparatus: A = anus; B = bucal mass; GD = venom bulb; $\mathrm{GG}=$ venom duct; $\mathrm{KN}=$ caecum of radular sac; $\mathrm{L}_{1}, \mathrm{~L}_{2}, \mathrm{~L}_{3}=$ liver; $\mathrm{MD}=$ middle gut; $\mathrm{MGM}=$ stomach muscle; $\mathrm{PH}=$ pharynx; $\mathrm{R}=$ circular muscles of proboscis; $\mathrm{RDS}=$ radular sac; $\mathrm{RT}=$ rectum; $\mathrm{SD}=$ salivary gland. B. Male reproductive apparatus: $\mathrm{EP}=$ epiphalus; $\mathrm{HA}=$ anterior lobe of testis; $\mathrm{HP}=$ posterior lobe of testis; $\mathrm{GH}=$ excretory duct of testis; $\mathrm{P}=$ penis; $\mathrm{PG}=$ prostate; $\mathrm{PGA}=$ anterior part of prostate; $\mathrm{PGD}=$ posterior part of prostate; $\mathrm{PGS}=$ final part of prostate; $\mathrm{VD}_{1}=$ vas deferens, anterior part; $\mathrm{VD}_{2}=$ vas defferens, thickened part; $\mathrm{VE}_{1}=$ vas efferens, posterior part; $\mathrm{VE}_{2}=$ vas efferens, anterior part. C. Nervous system: $\mathrm{C}=$ cerebral ganglion; $\mathrm{CB}=$ cerebral-buccal connective; $\mathrm{CP}=$ right cerebropedal connective; $\mathrm{CP}^{\prime}=$ left cerebropedal connective; IN = subintestinal ganglion; $\mathrm{LI}=$ left pleuro subintestinal connective; $\mathrm{LP}=$ left pleural ganglion; $\mathrm{P}=$ peda-ganglion; $\mathrm{PA}=$ right parietal nerve: $\mathrm{PA}^{\prime}=$ left parietal nerve; $\mathrm{PP}=$ right pleuropedal connective; $\mathrm{PP}{ }^{\prime}=$ left pleuropedal connective; $\mathrm{SP}=$ supra-intestinal ganglion; $\mathrm{T}=$ tentacular nerve; $\mathrm{V}=$ right visceral connective; $\mathrm{V}^{\prime}=$ left visceral connective. 


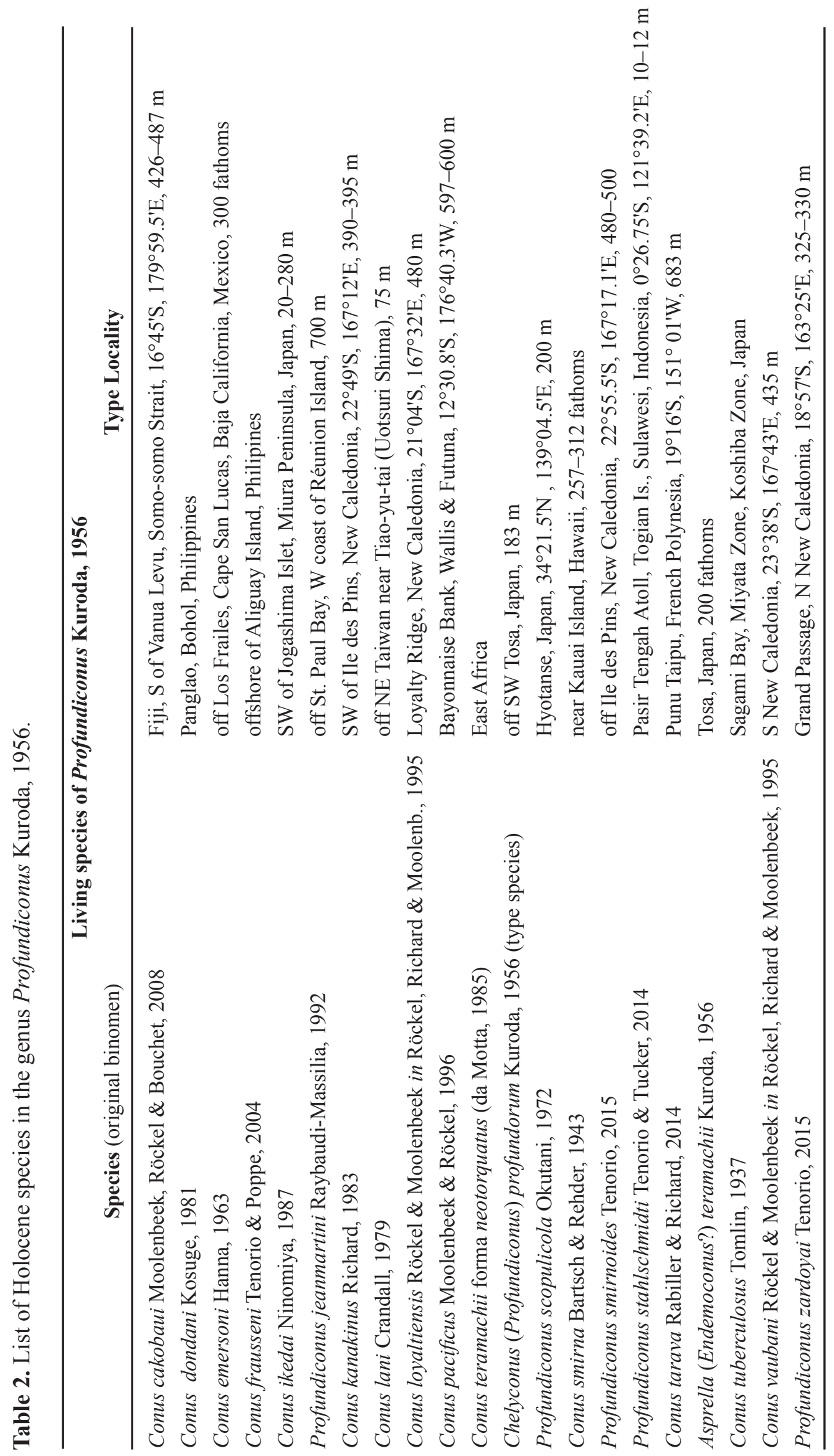




\section{Remarks}

The shells of species in Profundiconus are morphologically related to species included in the fossil genus Conilithes Swainson, 1840. Both taxa contain shells with square nodules that are interconnected by carinae on the body whorl, which constitutes a plesiomorphic trait. However, the anal notch is deep in Conilithes and shallow in Profundiconus. Furthermore, Rolán \& Raybaudi-Massilia (1994) have suggested that Conilithes antidiluvianus (Bruguière, 1792) (Fig. 1E) and P. teramachii (Fig. 1B) are close relatives. Based upon similarities in shell morphology Tucker \& Tenorio (2009) placed both genera, Conilithes and Profundiconus, within the family Conilithidae and separate from Conidae. However, shell traits can be ambiguous. The serrated operculum and the morphology of the radular tooth are more robust proxies for placing a given specimen in Profundiconus. The presence on the radular tooth of a laterally widened, often serrated external cusp, along with a characteristic fringe located immediately below the waist composed of closely spaced projections pointing towards the apex in addition to other morphological features (i.e., barb, pointed blade, shaft fold, etc.; see Fig. 2), allow the immediate identification of an individual as a member of Profundiconus. The function of the coronated fringe on the tooth in species of Profundiconus is unknown, but it resembles a similar structure (collar-shaped band of tubercles) observed on the radular teeth of several members of the genus Lienardia Jousseaume, 1884, family Clathurellidae, such as Lienardia tagaroae Fedosov, 2011, L. jousseaumei (Hervier, 1896) or L. cf. rosella Hedley, 1922 (Fedosov 2011; Bouchet et al. 2011).

Nothing is known about the diet of Profundiconus cone snails, nor about the families of conotoxins which might be present in the species of the genus. Whereas most of the toxinological studies on cone snails carried out during the last three decades have focused on species that belong to only a few lineages (Puillandre et al. 2012), several lineages remain largely understudied or even not studied at all, as is the case for Profundiconus (Puillandre et al. 2014). Radular morphology suggests a most likely vermivorous diet. However, Marshall (1981) reported finding the beaks of a small cephalopod in the stomach of an adult specimen of $P$. smirnoides (identified as smirna) from Wanganella Bank, New Zealand. This suggests that this species might produce a conotoxin of sufficient potency to rapidly immobilize a fastmoving prey.

\section{Phylogenetic analyses}

Ingroup sequences included 657 bp containing 192 variable sites, of which 127 were phylogenetically informative. Excluding redundant sequences, 27 sequences were unique in the ingroup. The ML and BA tree topologies were congruent (Fig. 5) and supported Profundiconus as a monophyletic group ( $\mathrm{PP}=1$; $\mathrm{BP}=87 \%$ ). Within Profundiconus, several clades corresponding to different species were recovered, although their phylogenetic relationships were poorly resolved (Fig. 5). The individuals belonging to P. teramachii were split into two separate monophyletic groups corresponding to different geographic regions, one with specimens from the Indian Ocean (Madagascar) and another with specimens from the Pacific Ocean (China, Papua New Guinea and Solomon Islands). This splitting has previously been reported and discussed by Puillandre et al. (2014). The specimens of P. teramachii from the Indian Ocean belong to the forma neotorquatus da Motta, 1985 (Tucker \& Tenorio 2013). In the Indian Ocean this species is widely distributed, from Somalia to South Africa (Natal), including Madagascar. According to the phylogeny and the genetic distances, the specimens from Madagascar deserve specific status, i.e., Profundiconus neotorquatus (da Motta, 1984), rather than consideration as a mere form of $P$. teramachii. In spite of the molecular divergence that exists between $P$. neotorquatus and P. teramachii, the morphological differences in their shells (Fig. 1B-C) and radulae (Fig. 6) are slight.

The genetic differentiation of $P$. smirnoides and P. teramachii was not supported. Moreover, the monophyly of the group was not supported by the ML and BA analyses. Reciprocal monophyly between this group and $P$. neotorquatus was therefore not demonstrated. This is usually the case for recently diverged species, due to the lack of time needed to coalesce (Knowles \& Carstens 2007). It is interesting 
to note that one of the coxl sequences of P. smirnoides in GenBank (KJ550448) is essentially identical to that of $P$. teramachii, which represents the haplotype for 18 specimens (Table 1). As the voucher specimen (MNHN IM-2009-18244) seems to be properly identified, this could be due to contamination. However, there also exists the possibility that the coxl can simply not separate these two species, which on the other hand can be easily separated based on shell and radular morphologies. There are many examples in the literature of morphologically distinct species having identical or almost identical cox 1 sequences (e.g., Mengual et al. 2006; McGuire et al. 2007; April et al. 2011; Chee 2014). In most cases this has been attributed to hybridization-mediated mitochondrial introgression, as well as incomplete lineage sorting.

Specimens attributed a priori to the species Profundiconus loyaltiensis (Röckel \& Moolenbeek, 1995) based on shell morphology were segregated into two distinct lineages. One of these lineages formed a monophyletic group $(\mathrm{PP}=1 ; \mathrm{BP}=83 \%$ ) along with specimens assigned to $P$. vaubani (Röckel \& Moolenbeek, 1995) and P. kanakinus (Richard, 1983). Furthermore, some specimens of P. vaubani and $P$. loyaltiensis share the same haplotype. It is not clear at this stage whether this indicates one single polymorphic species, contamination, or simply the failure to separate the three closely related species based upon the coxl gene fragment only. All of these specimens come from the same area (Isle of Pines,

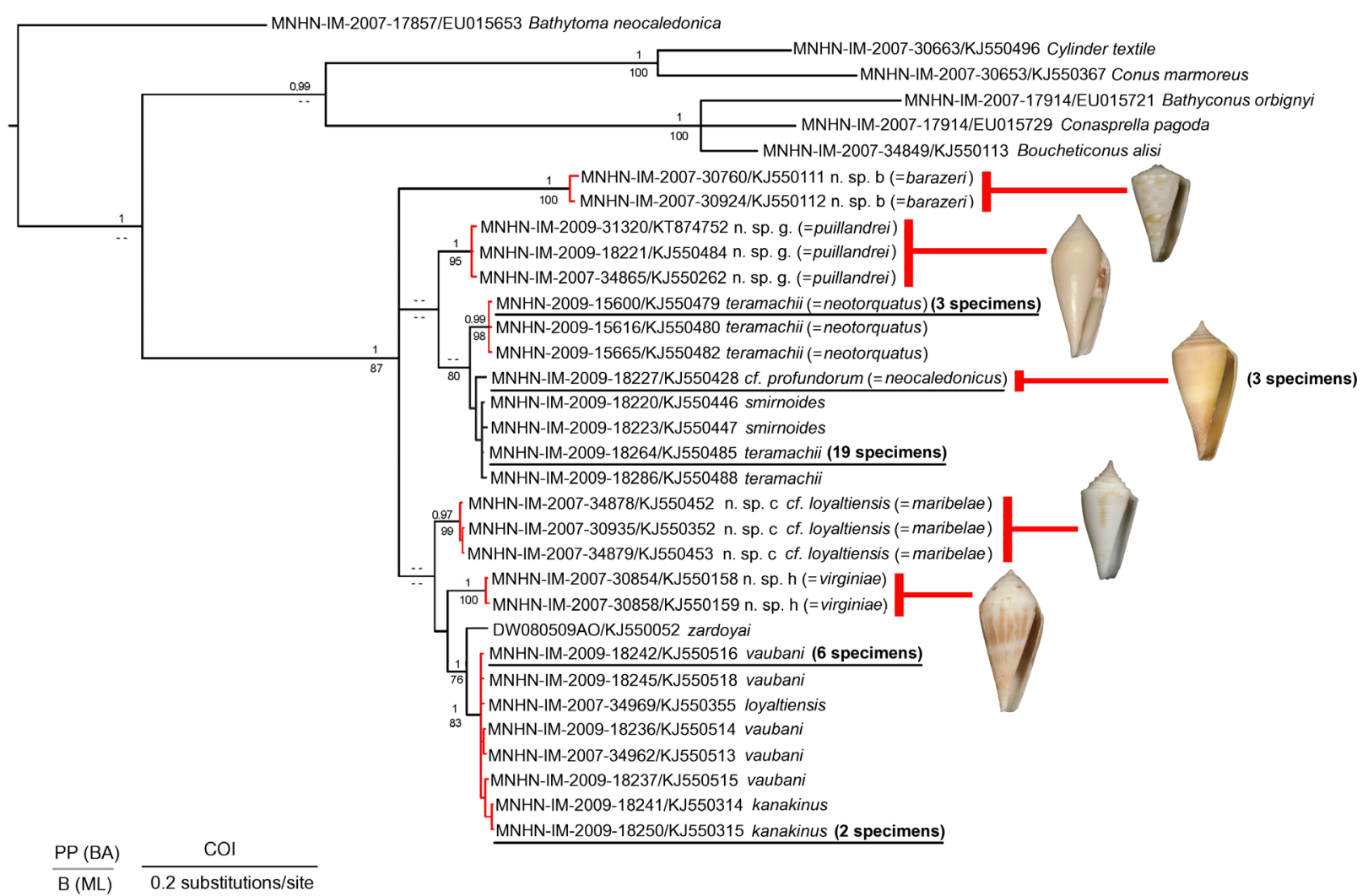

Fig. 5. Likelihood phylogenetic tree of Profundiconus Kuroda, 1956 based on a subsample of the mitochondrial coxl dataset produced by Puillandre et al. (2014). Posterior probabilities and bootstrap values are indicated for each node (when $\mathrm{PP} \geq 0.95 \%$ and $\mathrm{BP} \geq 75 \%$, respectively). For clarity purposes, external branches of phylogenetically highly supported species are highlighted in red in the consensus tree. Cox 1 sequences are labelled using the MNHN voucher identification number, the Genbank accession number (when available), the species name and the number of specimens (or identical haplotypes) when greater than 1. 
South New Caledonia). The group of specimens from the Solomon Islands labelled as "Profundiconus n. sp. cf. loyaltiensis" was monophyletic and highly supported by BA and ML analyses (PP = 0.97; $\mathrm{BP}=99$ ). If we assume that the specimens from New Caledonia are the genuine representatives of a population of the taxon P. loyaltiensis, we have to postulate that the specimens from the Solomon Islands belong to a separate group deserving recognition at the species level. The new species is introduced here under the name P. maribelae sp. nov. This taxon had previously been labelled as "Profundiconus $\mathrm{n}$. $\mathrm{sp}$. c cf. loyaltiensis" (Puillandre et al. 2014).

There are two groups containing specimens from Plateau des Chesterfield, and one with specimens from Norfolk Ridge and Loyalty Ridge, which do not match any known species of Profundiconus described to date. They are respectively introduced here as $P$. virginiae sp. nov., P. barazeri sp. nov. and P. puillandrei sp. nov. (previously considered in Puillandre et al. 2014 as "Profundiconus n. sp. h", "n. sp. b" and "n. sp. g", respectively). Additionally, we found that in spite of the lack of support at the corresponding nodes in the tree, the specimens ( 3 individuals sharing identical haplotype) corresponding to $P$. cf. profundorum from Norfolk Ridge exhibit significant conchological differences with the nominal taxon P. profundorum known from Japan and China. Based upon these constant differences and the independent branch in the tree, we describe it here as P. neocaledonicus sp. nov.
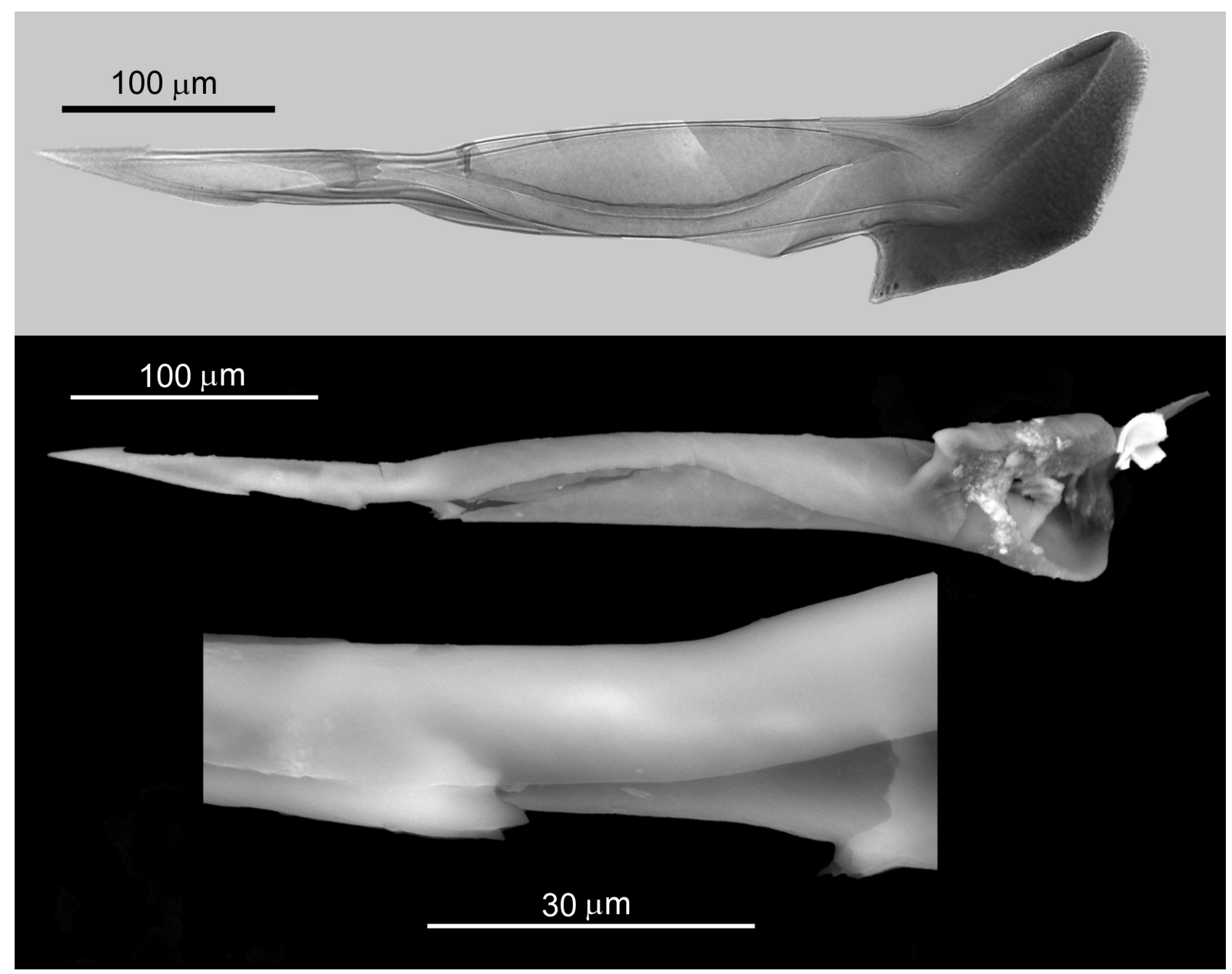

Fig. 6. Radular teeth extracted from Profundiconus neotorquatus (da Motta, 1984). A. Optical photograph (MJT coll., Mozambique, $\mathrm{S}_{\mathrm{L}} 68.9 \mathrm{~mm}$ ). B. SEM photograph (MNHN IM-2009-15641, South Madagascar, $\mathrm{S}_{\mathrm{L}} 48.7 \mathrm{~mm}$ ). C. Enlargement of the middle section of B. 


\section{Profundiconus maribelae sp. nov. urn:Isid:zoobank.org:act:8CAB54B6-D03A-49B7-A289-3F46FCCA9366}

Figs $7 \mathrm{~A}-\mathrm{G}, 8$

Profundiconus n. sp. c cf. loyaltiensis - Puillandre et al. 2014: Supplementary Material 1 (unfigured).

\section{Etymology}

This species is dedicated to Maribel Albarrán Quintanilla, wife of the first author and a shell-lover, in recognition for her support and constant encouragement to the first author at all times.

\section{Type material examined}

\section{Holotype}

SOLOMON ISLANDS: $27.5 \times 12.6 \mathrm{~mm}, \mathrm{R} / \mathrm{V}$ Alis, SALOMONBOA 3 Expedition, st. CP 2767 , Guadalcanal, $9^{\circ} 19^{\prime}$ S, $160^{\circ} 6^{\prime}$ E, 416-425 m (MNHN IM-2007-34878; Fig. 7A; GenBank accession number (coxl sequence): KJ550452).

\section{Paratypes}

SOLOMON ISLANDS: $30.0 \times 12.5 \mathrm{~mm}, \mathrm{R} / \mathrm{V}$ Alis, SALOMON 2 Expedition, st. CP 2207, NW Isabel, 7²3' S, 158²9' E, 336-341 m (MNHN IM-2007-30935; paratype 1; Fig. 7B; GenBank accession number (coxl sequence): KJ550352); $30.4 \times 13.1 \mathrm{~mm}, \mathrm{R} / \mathrm{V}$ Alis, SALOMON 2 Expedition, st. CP 2247, NW Isabel, 7²4' S, 156² 25' E, 686-690 m (MNHN IM-2007-30338; paratype 2; Fig. 7C); $27.2 \times 12.4 \mathrm{~mm}$ (broken shell), R/V Alis, SALOMONBOA 3 Expedition, type locality, 416-425 m (MNHN IM-200734880; paratype 3; Fig. 7E).

\section{Type locality}

SOLOMON ISLANDS: Guadalcanal, 9¹9' S, 1606' E, 416-425 m (SALOMONBOA 3 st. CP 2767).

\section{Other material examined}

SOLOMON ISLANDS: $31.5 \times 14.4 \mathrm{~mm}, \mathrm{R} / \mathrm{V}$ “Alis", SALOMONBOA 3 Expedition, type locality (MNHN IM-2007-34879; Fig. 7F; GenBank accession number (cox1 sequence): KJ550352). Note: This specimen was photographed (http://coldb.mnhn.fr/catalognumber/mnhn/im/2007-34879) and sequenced, but the shell was destroyed in the process and is no longer available.

\section{Description}

Morphometric parameters: $\mathrm{S}_{\mathrm{L}}=27-32 \mathrm{~mm} ; \mathrm{RD}=0.55-0.62 ; \mathrm{RSH}=0.21-0.26 ; \mathrm{PMD}=0.89-0.93$.

Shell moderately small. Maximum length $31.5 \mathrm{~mm}$. Shell profile conical, with straight to very slightly convex sides and spire moderate to high. Spire profile straight, stepped. Paucispiral protoconch with 1.5-1.75 whorls, brownish, glossy and translucent (Fig. 7D). Teleoconch whorls stepped, ridged with small but strong nodules which persist in shoulder in most cases. Sutural ramp concave, with subsutural ridge and 3 to 4 strong spiral cords crossed by thin radial threads. Shoulder carinated, most often covered with small nodules along shoulder angle. Early teleoconch whorls pure white. Late teleoconch whorls in vicinity of shoulder area may exhibit some small, irregular brown blotches. Last whorl with grooves forming flat spiral ribbons, which may extend from shoulder to base. In some specimens sculpture of grooves and flat spiral ribbons in last whorl reduced to subshoulder area and basal half. Ground colour white overlaid with sparse brown, axially arranged flammules or blotches. White ground colour predominates in all specimens studied. Columella and aperture white. Anal notch shallow. Periostracum yellow-brown, thin and translucent. Operculum present, serrated on left border. 


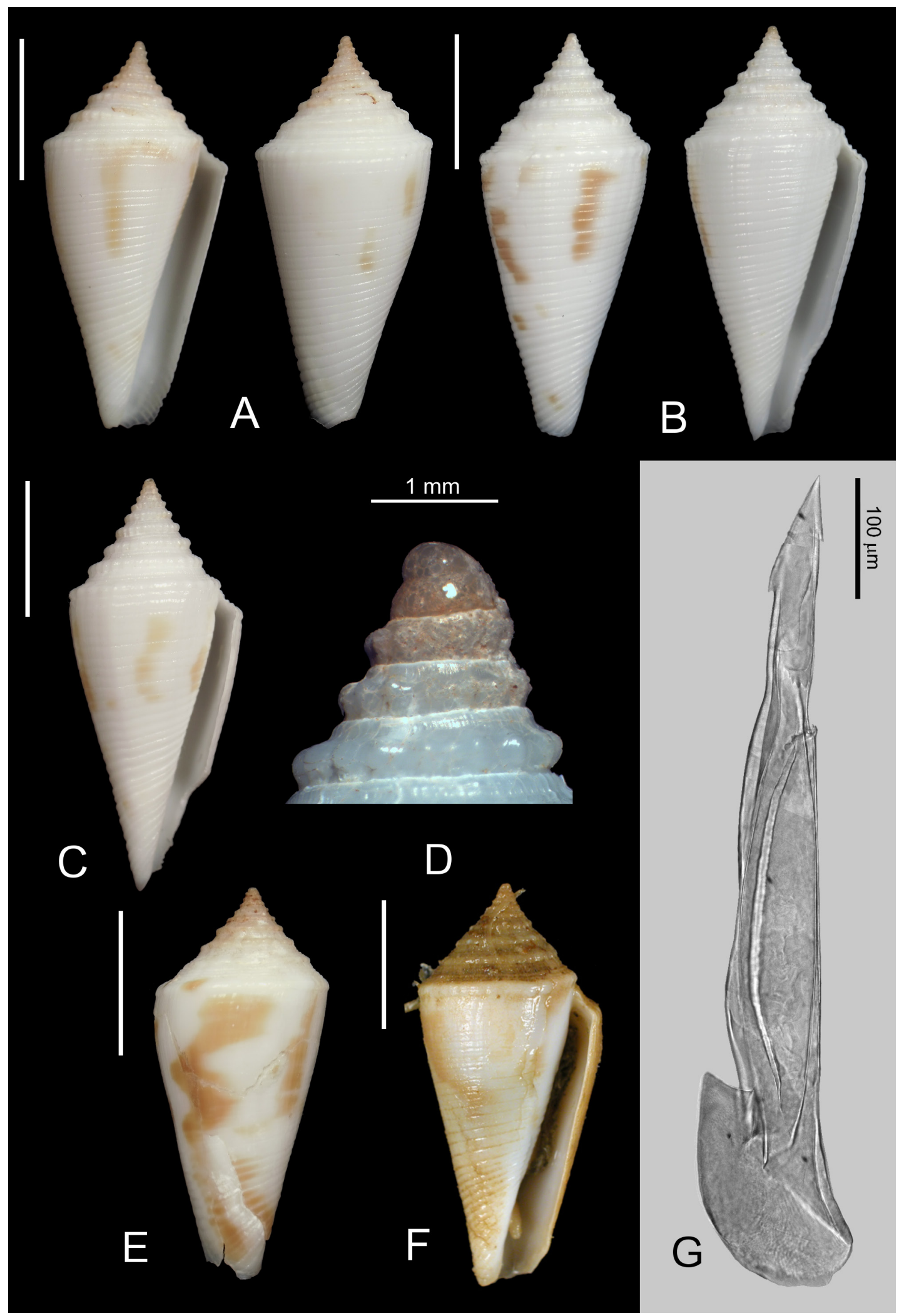

Fig. 7. Profundiconus maribelae sp. nov. A. Holotype, $27.5 \times 12.6 \mathrm{~mm}$. B. Paratype $1,30.0 \times 12.5 \mathrm{~mm}$. C. Paratype 2, $30.4 \times 13.1 \mathrm{~mm}$. D. Paratype 2, enlargement of the spire. E. Paratype 3 (broken shell), $27.2 \times 12.4 \mathrm{~mm}$. F. Sequenced specimen (MNHN IM-2007-34879), $31.5 \times 14.4 \mathrm{~mm}$. G. Radular tooth from paratype 1 . Scale bars $=10 \mathrm{~mm}$ unless otherwise indicated. 
Radular teeth examined in paratype 1 (Fig. 7G). 38 teeth in radular sac. Radular tooth medium-sized, its total length relative to shell length $\mathrm{S}_{\mathrm{L}} / \mathrm{T}_{\mathrm{L}}=45$. Anterior portion much shorter than posterior section of tooth $\left(\mathrm{T}_{\mathrm{L}} / \mathrm{AP}_{\mathrm{L}}=3.43\right)$. With one barb and pointed, well-defined blade which covers $50 \%$ of anterior portion of tooth. With external cusp located at approximately lower quarter of anterior portion of tooth, extending between $75 \%$ and $90 \%$ of length of anterior portion of tooth. External cusp laterally expanded and serrated, with 5 small denticles. Immediately below waist with characteristic fringe composed of closely spaced projections pointing towards apex. Shaft fold present. Large and prominent basal spur present on top of slanted base of tooth.

\section{Distribution and habitat}

Known from the Solomon Islands, including the New Georgia Group (Vella Lavella Island), Santa Isabel and Guadalcanal, at depths between 336 and 690 m (Fig. 8).

\section{Remarks}

The specimens of $P$. maribelae sp. nov. from the Solomon Islands form a monophyletic group supported by $\mathrm{BI}$ and ML analyses. P. maribelae sp. nov. was initially referred to as $P$. cf. loyaltiensis in the phylogenetic analysis, given the resemblance of its shell to that of $P$. loyaltiensis, a species known only from New Caledonia (Fig. 1H). However, the shell of P. maribelae sp. nov. attains a larger size (27-32 mm for maribelae vs. 21.5-26 mm for loyaltiensis). The spire outline in P. maribelae sp. nov. is straight rather than deeply concave as occurs in P. loyaltiensis. The sculpture of flat spiral ribbons in the last whorl is much more developed in $P$. maribelae sp. nov. than in P. loyaltiensis. The most evident difference between the two species is that the shell of $P$. loyaltiensis is white and patternless, whereas the shell of $P$. maribelae sp. nov. exhibits a pattern of sparse, axially arranged brown flammules or blotches. The morphology of the radular teeth of $P$. maribelae sp. nov. and $P$. loyaltiensis is very similar, but they

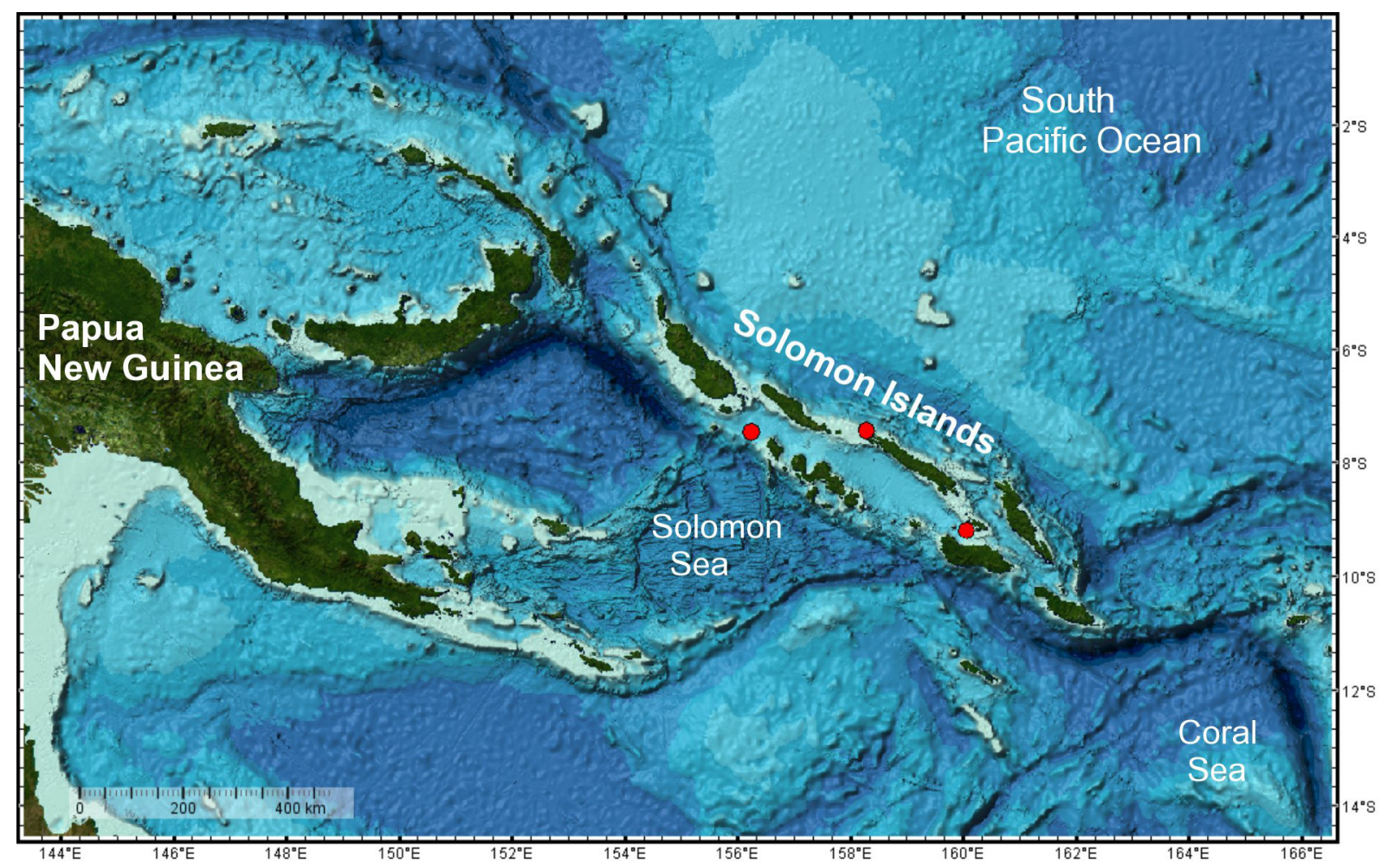

Fig. 8. Distribution map for Profundiconus maribelae sp. nov. Red circles indicate the points where the species has been collected. 
differ in their relative sizes, being larger in P. loyaltiensis $\left(\mathrm{S}_{\mathrm{L}} / \mathrm{T}_{\mathrm{L}}\right)=30-37$; versus 45 for P. maribelae sp. nov.). The shell of $P$. teramachii (Fig. 1B) is easily separated from that of $P$. maribelae sp. nov. by its much larger size, its pale, straw-yellow, patternless shell, smooth sculpture of the last whorl, usually much less developed nodules, absence of strong cords on the sutural ramp, and by its multispiral instead of paucispiral protoconch. P. maribelae sp. nov. is distantly related to both $P$. loyaltiensis and $P$. teramachii in the phylogeny presented here.

Profundiconus virginiae sp. nov.

urn:1sid:zoobank.org:act:1785F28A-89FA-40FC-B28A-68E828B3F0A9

Figs $9 \mathrm{~A}-\mathrm{D}, \mathrm{G}, 10$

Profundiconus n. sp. h - Puillandre et al. 2014: Supplementary Material 1 (unfigured).

Profundiconus cf. cakobaui - Tenorio 2015a: 37 (unfigured; non Conus cakobaui Moolenbeek, Röckel \& Bouchet, 2008).

\section{Etymology}

This species is dedicated to Virginie Héros, assistant curator of molluscs at the Muséum national d'Histoire naturelle of Paris (MNHN) and an experienced member of the numerous collecting expeditions carried out by this institution. Her contribution to our knowledge of the New Caledonian deep-water cones is recognised by naming this remarkable new species of Profundiconus after her.

\section{Material examined}

\section{Holotype}

NEW CALEDONIA: $42.5 \times 19.4 \mathrm{~mm}, \mathrm{R} / \mathrm{V}$ Alis, EBISCO Expedition, st. DW 2613, Plateau des Chesterfield, 193' S, 158 42' E, 519-522 m (MNHN IM-2007-30854; Fig. 9A; GenBank accession number (coxl sequence): KJ550158).

\section{Paratypes}

NEW CALEDONIA: $33.3 \times 16.5 \mathrm{~mm}$, R/V Alis, EBISCO Expedition, type locality, 431-436 m (MNHN IM-2007-30858; paratype 1; Fig. 9B; GenBank accession number (coxl sequence): KJ550159); $16.3 \times 13.0 \mathrm{~mm}, \mathrm{R} / \mathrm{V}$ Alis, EBISCO Expedition, st. DW 2610, Plateau des Chesterfield, 19³4' S, 158 $41^{\prime}$ E, 486-494 m (MNHN IM-2000-30789; paratype 2; Fig. 9D; fragment of the spire, well preserved).

\section{Type locality}

NEW CALEDONIA: Coral Sea, Plateau des Chesterfield, 19³7' S, 158 $42^{\prime}$ E, 519-522 m (EBISCO st. DW 2613).

\section{Description}

Morphometric parameters: $\mathrm{S}_{\mathrm{L}}=33-43 \mathrm{~mm} ; \mathrm{RD}=0.59-0.63 ; \mathrm{RSH}=0.21-0.23 ; \mathrm{PMD}=0.82-0.83$.

Shell moderately small to medium sized. Maximum length $42.5 \mathrm{~mm}$. Shell profile ventricosely conical, with spire moderate to high. Spire profile sigmoid. Multispiral protoconch with 3-3.5 whorls, white, glossy and translucent (Fig. 9C). Early 4-5 teleoconch whorls stepped, ridged with small nodules which tend to disappear after fifth whorl. Sutural ramp flat to slightly concave, with 3 to 6 fine spiral cords becoming obsolete in late spire whorls. Shoulder subangulate, forming characteristic ridge, covered with axial costae on last whorl. Early teleoconch whorls creamy white with brown spiral band on periphery, extending over row of nodules. On later whorls, this brown band interrupted by white areas. Spire creamy white with sparse, small brown blotches in areas near suture. Last whorl smooth or with very fine striae and with spiral ribs on basal third. Ground colour creamy white overlaid with orange-brown 

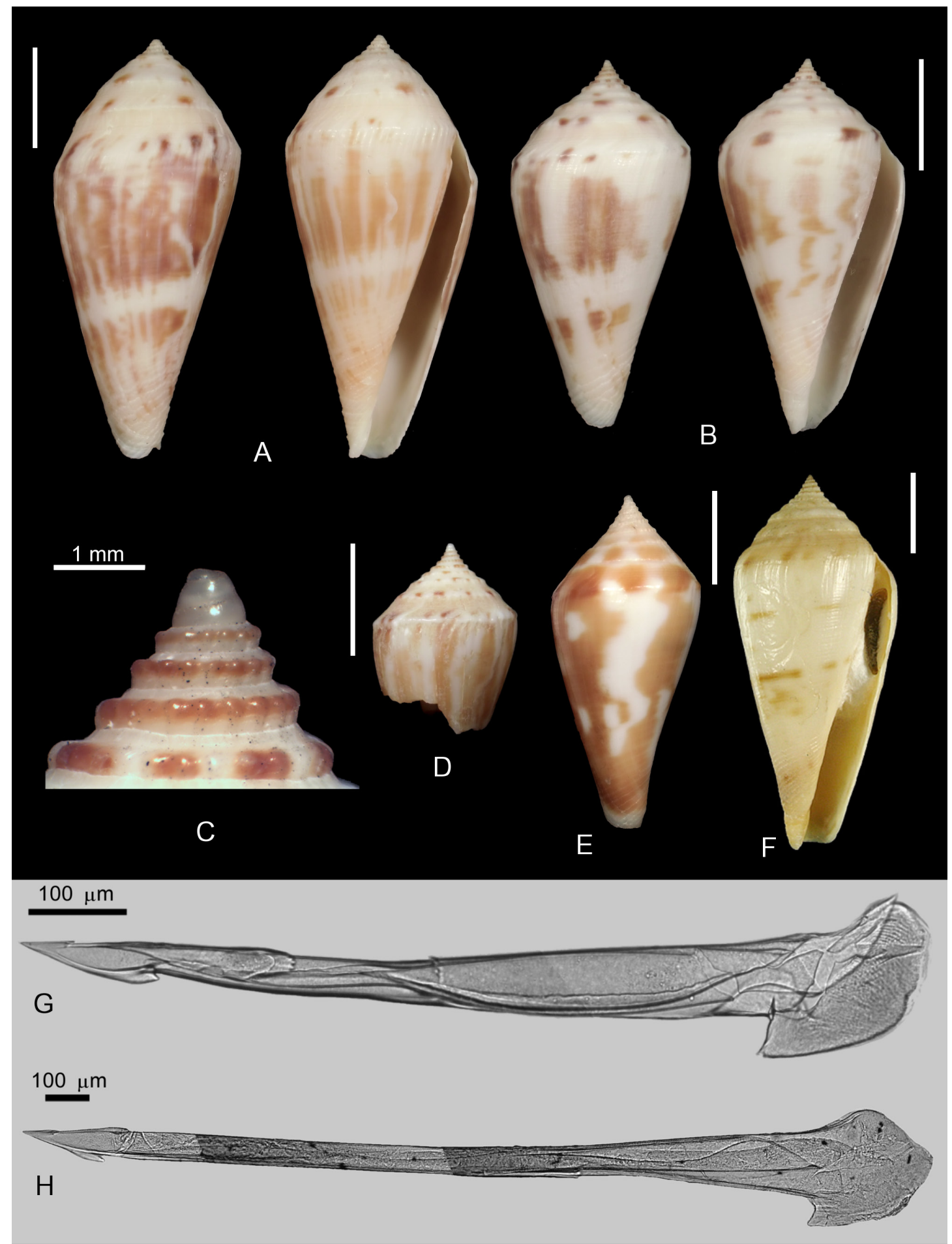

Fig. 9. - A-D. Profundiconus virginiae sp. nov. A. Holotype, $42.5 \times 19.4 \mathrm{~mm}$. B. Paratype 1, $33.3 \times$ $16.5 \mathrm{~mm}$. C. Paratype 1, enlargement of the spire. D. Paratype 2 (fragment), $16.3 \times 13.0 \mathrm{~mm}$. E. Profundiconus cf. cakobaui Moolenbeek et al., 2008 (MJT coll., Balut Is., Mindanao, Philippines, 450-500 m), $35.8 \times 16.3 \mathrm{~mm}$. - F. Profundiconus frausseni (Tenorio \& Poppe, 2004) (holotype, NMP, Aliguay Island, Philippines, $100-150 \mathrm{~m}), 47.0 \times 21.0 \mathrm{~mm}$. - G. Radular tooth of Profundiconus virginiae sp. nov. from the holotype. - H. Radular tooth, Profundiconus smirnoides Tenorio, 2015 (MNHN IM-2000-30058, Norfolk Ridge, New Caledonia), S $81.4 \mathrm{~mm}$. Scale bars $=10 \mathrm{~mm}$ unless otherwise indicated. 
to purplish brown, irregular blotches or axially arranged flammules, interrupted by ground-colour band at midbody. Columella white. Aperture creamy white. Anal notch shallow. Periostracum and operculum not observed.

Radular teeth examined in holotype (Fig. 9G) and in paratype 1.48 to 53 teeth in radular sac. Radular tooth medium to large-sized, its total length relative to shell length $S_{L} / T_{L}=37-45$, rather elongated. Waist poorly defined. Anterior portion shorter than posterior section of tooth $\left(\mathrm{T}_{\mathrm{L}} / \mathrm{AP}_{\mathrm{L}}=2.61-2.70\right)$. With one barb and pointed, well-defined blade which covers $40-43 \%$ of anterior portion of tooth. With external cusp located at approximately lower third of anterior portion of tooth, extending between $60 \%$ and $81 \%$ of length of anterior portion of tooth. External cusp laterally expanded and serrated, with 5-6 small denticles. With characteristic fringe of closely spaced projections pointing towards apex located immediately below waist. Shaft fold present. Large and prominent basal spur on top of slanted base of tooth.

\section{Distribution and habitat}

Only known from the Coral Sea, Plateau des Chesterfield area, New Caledonia (Fig. 10).

\section{Remarks}

Profundiconus virginiae sp. nov. was initially misidentified as $P$. smirnoides (Fig. 1D). The latter has a fusiform shell, larger in size $\left(\mathrm{S}_{\mathrm{L}}=52-98 \mathrm{~mm}\right.$; versus $\left.33-43 \mathrm{~mm}\right)$, more slender $(\mathrm{RD}=0.46-0.56$; versus $0.59-0.63)$ and with a higher spire $(\mathrm{RSH}=0.25-0.36$; versus $0.21-0.23$ ) than $P$. virginiae sp. nov. The shell of $P$. smirnoides has a pattern consisting of a brown spiral band on each side of centre, interrupted by creamy white axial streaks, but lacks the axial costae on the ridge. The radular teeth of $P$. virginiae sp. nov. and P. smirnoides also differ. The latter has a very elongated radular tooth (Fig. 9H), with the

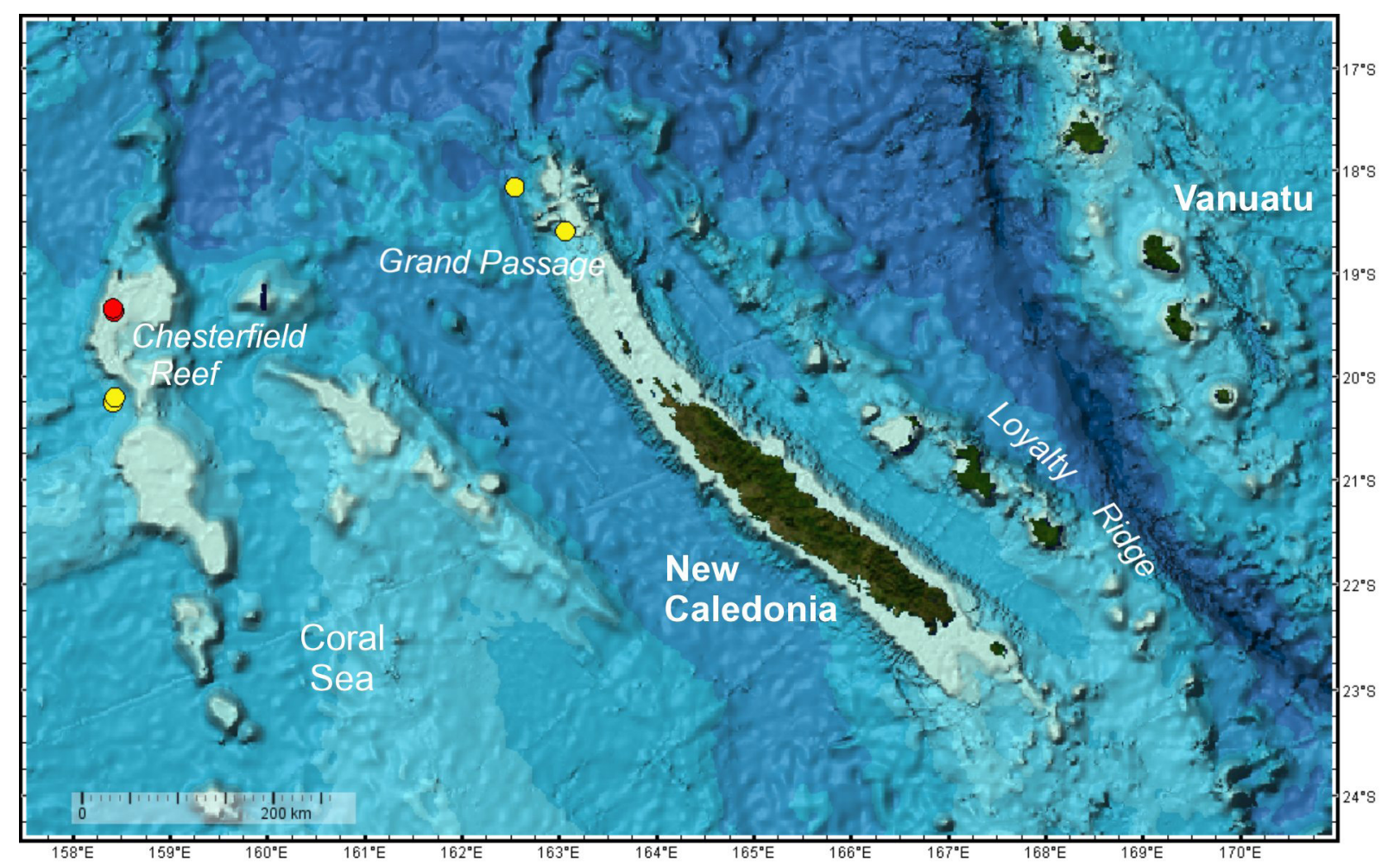

Fig. 10. Distribution map for Profundiconus virginiae sp. nov. (red circles) and P. barazeri sp. nov. (yellow circles). Symbols indicate the points where each of the species have been collected. 
anterior and posterior sections difficult to separate (Tenorio 2015b). Still, the anterior section of the tooth in adult $P$. smirnoides is longer than the posterior section $\left(\mathrm{T}_{\mathrm{L}} / \mathrm{AP}_{\mathrm{L}}=1.7-1.8\right)$. The strongly pointed blade covers less than $25 \%$ of the anterior section. The external cusp is pointed, not expanded laterally and is not serrated, in contrast to $P$. virginiae sp. nov. Interestingly, in $P$. smirnoides the external cusp occupies a very high position in the anterior section, extending from 20 to $30 \%$ of its length (i.e., almost the same position as the blade, but with a different orientation).

P. virginiae sp. nov. resembles no other species of Profundiconus. Although only two live-taken specimens and the spire of a broken shell of this species have been examined, their shell and radula features, as well as the phylogenetic analysis, warrant its description as a new species. Apart from P. smirnoides, $P$. virginiae sp. nov. can be compared to P. vaubani from New Caledonia (Fig. 1I), and to P. cakobaui from the Fiji Islands (Fig. 1K) and P. cf. cakobaui (Fig. 9E) from the Philippines. P. vaubani also has axial costae and brown elements on the shell pattern. However, its paucispiral protoconch readily separates this species from $P$. virginiae sp. nov., which has a multispiral protoconch and appears rather distant from P. vaubani on the tree shown in Fig. 5. P. cakobaui and P. cf. cakobaui exhibit a shell pattern similar to that of $P$. virginiae sp. nov., including the brown spiral band on the periphery of the early teleoconch whorls extending over the row of nodules. However, both have a paucispiral protoconch instead of multispiral, and both lack the characteristic axial costae present in P. virginiae sp. nov. at the shoulder ridge. The elusive species P. frausseni (Tenorio \& Poppe, 2004) (Fig. 9F), known only from a few specimens collected in the Philippines, has a protoconch and early teleoconch resembling that of $P$. virginiae sp. nov. However, the multispiral protoconch is white in $P$. virginiae sp. nov., but cream-coloured in P. frausseni (Tenorio \& Poppe 2004). The latter is lower spired (RSH $=0.19-0.21$; versus $0.21-0.23$ ) and more conical $(\mathrm{PMD}=0.87-0.89$; versus $0.82-0.83$ ) than $P$. virginiae sp. nov. Cords on the teleoconch whorls of $P$. frausseni are more developed, whereas they become obsolete on the late whorls in P. virginiae sp. nov. The shoulder in P. frausseni is rounded (subangulate in juvenile specimens), whereas in P. virginiae sp. nov. it is subangulate and ridged, covered with axial costae which are absent in $P$. frausseni. The scarce number of specimens of $P$. virginiae sp. nov. available prevented any statistical comparison of shell morphometry among different taxa. The two individuals of $P$. virginiae sp. nov. form a monophyletic group in the phylogeny that is the sister group of $P$. zardoyai, P. vaubani, P. loyaltiensis and P. kanakinus.

Profundiconus barazeri sp. nov. urn:1sid:zoobank.org:act:3D0659AE-4433-41C4-B03A-BFED9523E1EE

Figs $10,11 \mathrm{~A}-\mathrm{G}, \mathrm{K}$

Profundiconus n. sp. b - Puillandre et al. 2014: Supplementary Material 1 (unfigured).

\section{Etymology}

At the request of Prof. Philippe Bouchet from MNHN, this new species is named after Captain JeanFrançois Barazer, first captain on IRD's research vessel Alis, in recognition of his dedication to, and expertise in, deep-sea exploration in the South and West Pacific. Many new species have been discovered during the cruises that he has skilfully commanded.

\section{Material examined}

\section{Holotype}

NEW CALEDONIA: $11.6 \times 7.0 \mathrm{~mm}, \mathrm{R} / \mathrm{V}$ Alis, EBISCO Expedition, st. DW 2564, NW Bellona Reef, Plateau des Chesterfield, 20²5' S, 158 ${ }^{\circ} 41^{\prime}$ E, 333-386 m (MNHN IM-2007-30760; Fig. 11 A; GenBank accession number (coxl sequence): KJ550111). 
Paratypes

NEW CALEDONIA: $14.5 \times 8.6 \mathrm{~mm}$, collecting data as for holotype (MNHN IM-2007-30924; paratype 1; Fig. 11B; GenBank accession number (coxl sequence): KJ550112); $16.5 \times 9.9 \mathrm{~mm}, \mathrm{R} / \mathrm{V}$ Alis, EBISCO Expedition, st. DW 2576, N Bellona Reef, Chesterfield, 20²0' S, 158 43' E, 390-394 m (MNHN IM-2000-30790; paratype 2; Fig. 11C); $10.3 \times 6.2 \mathrm{~mm}, \mathrm{R} / \mathrm{V}$ Alis, CONCALIS Expedition, st. DW 2985, Grand Passage, Northern New Caledonia, 1859' S, 16306' E, 277-289 m (MNHN IM-2000-30791; paratype 3; Fig. 11D); $10.6 \times 5.5 \mathrm{~mm}$, collecting data as for preceding (MNHN IM2000-30792; paratype 4; Fig. 11E); $10.5 \times 5.6 \mathrm{~mm}, \mathrm{R} / \mathrm{V}$ Alis, CONCALIS Expedition, st. DW 2979, Grand Passage, N New Caledonia, 18 ${ }^{\circ} 16^{\prime}$ S, 162 $2^{\circ} 4^{\prime}$ E, 350 m (MNHN IM-2000-30777; paratype 5; Fig. 11G).

\section{Type locality}

NEW CALEDONIA: Coral Sea, NW Bellona Reef, Plateau des Chesterfield, 20²5' S, $158^{\circ} 41^{\prime}$ E, $333-$ $386 \mathrm{~m}$ (EBISCO st. DW 2564).

\section{Description}

Morphometric parameters: $\mathrm{S}_{\mathrm{L}}=10-15 \mathrm{~mm} ; \mathrm{RD}=0.63-0.69 ; \mathrm{RSH}=0.11-0.19 ; \mathrm{PMD}=0.90-0.95$.

Shell very small (maximum length $16.5 \mathrm{~mm}$ ). Shell profile conical, with spire low to moderate in height. Spire profile straight. Shoulder angulated, with distinct rim. Last whorl with straight sides, smooth, with some grooves in basal quarter, which appears slightly deflected to the left. Protoconch white, porcellaneous, with 1.5 whorls (Fig. 11F). Early teleoconch whorls with small nodules which are lost after whorl 3. Sutural ramp flat to slightly concave, slightly stepped, bearing 3-5 strong cords, with smooth ridge above suture. Spire white, with yellow-brown blotches on ridge above suture. Ground colour pale orange-brown to creamy white. Last whorl with pattern of pure white dashes and dots arranged in spiral lines, often alternating with dashes of orange-brown. Sparse small, diffuse rounded, orange-brown spots occasionally present. Holotype just below midbody with orange-brown narrow band overlaid with white dashes arranged in spiral, absent in other specimens examined, some of which are patternless. Columella and aperture white.

Radular tooth examined in holotype (Fig. $11 \mathrm{~K}$ ) and paratype 1.45 teeth in radular sac. Radular tooth of rather large relative size: its total length relative to shell length $S_{L} / T_{L}=26-30$. Anterior portion much shorter than posterior section of tooth $\left(\mathrm{T}_{\mathrm{L}} / \mathrm{AP}_{\mathrm{L}}=3.7-3.8\right)$. With one barb and pointed, well-defined blade, which covers $48-61 \%$ of apical portion of tooth. External cusp present, extending between 80 and $96 \%$ of length of anterior portion of tooth. External cusp laterally widened and serrated, with 7-9 small denticles. Large adapical opening occupying most of anterior portion of tooth $\left(100 \mathrm{AO}_{\mathrm{L}} / \mathrm{AP}_{\mathrm{L}}=64-70\right)$. With characteristic fringe of closely spaced projections pointing towards the apex located immediately below waist. Shaft fold present. Large and prominent basal spur on top of slanted base of tooth.

Fig. 11. [opposite page]-A-G. Profundiconus barazeri sp.nov. A. Holotype, $11.6 \times 7.0 \mathrm{~mm}$. B. Paratype 1, $14.5 \times 8.6 \mathrm{~mm}$. C. Paratype 2, $16.5 \times 9.9 \mathrm{~mm}$. D. Paratype 3, $10.3 \times 6.2 \mathrm{~mm}$. E. Paratype 4, $10.6 \times 5.5$ mm. F. Paratype 5, enlargement of the spire. G. Paratype 5, $10.5 \times 5.6 \mathrm{~mm}$. - H. Boucheticonus alisi (Moolenbeek et al., 1995) (holotype, MNHN IM-2000-2588, Norfolk Ridge, New Caledonia, 330$367 \mathrm{~m}$ ), $22.2 \mathrm{~mm}$. - I. Profundiconus zardoyai Tenorio, 2015 (holotype, MNHN IM-2000-28206, Grand Passage, New Caledonia, 325-330 m), $10.5 \mathrm{~mm}$. - J. Continuconus estivali (Moolenbeek \& Richard, 1995) (holotype, MNHN IM-2000-2566, Plateau des Chesterfield, New Caledonia, 400 m), $10.5 \mathrm{~mm}$. - K. Radular tooth of Profundiconus barazeri sp. nov. from the holotype. - L. Radular tooth, Boucheticonus alisi (Moolenbeek et al., 1995) (Atheris voucher DW080502AD, New Caledonia), $\mathrm{S}_{\mathrm{L}} 19.0 \mathrm{~mm}$. Scale bars $=10 \mathrm{~mm}$ unless otherwise indicated. 

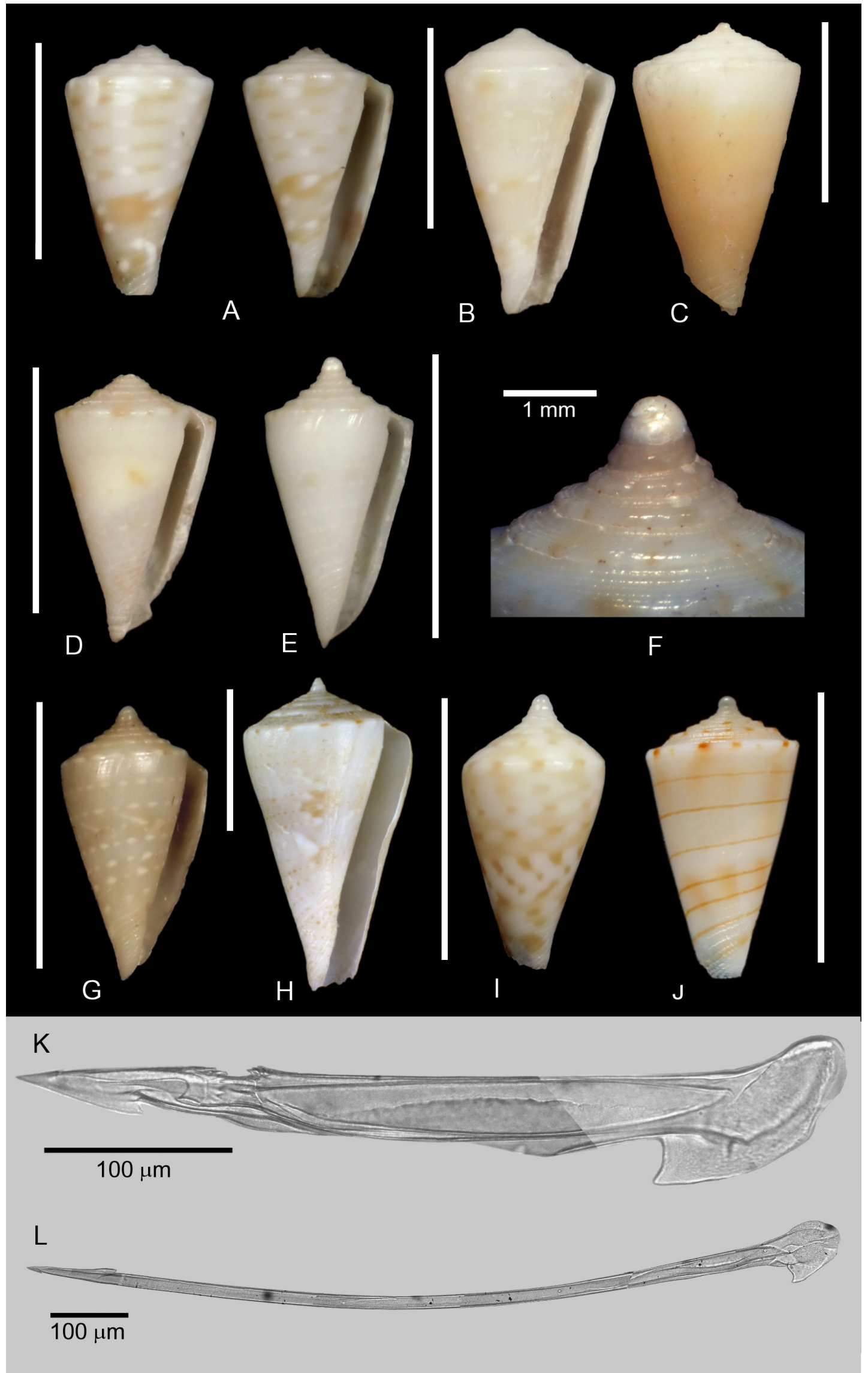


\section{Distribution and habitat}

Specimens from two separate populations in New Caledonia are known: from NW Bellona Reef, Plateau des Chesterfield (type locality), and from the Grand Passage area; at depths from 277 to $350 \mathrm{~m}$ (Fig. 10).

\section{Remarks}

P. barazeri sp. nov. resembles in general aspect a small specimen of Boucheticonus alisi (Fig. 11H). The latter has a larger shell, variably patterned, with a multispiral protoconch, which exhibits a characteristic brown blotch. The protoconch is paucispiral in P. barazeri sp. nov. These two species are phylogenetically distant (Fig. 5) and have very different radular morphologies. In contrast to the tooth of P. barazeri sp. nov., the radular tooth of $B$. alisi (Fig. 11L) is very large and elongated, with an extremely long anterior section that is more than four times longer than the posterior section of the tooth. It has a small and indistinct barb opposite a blade, which is enlarged and widened laterally. P. barazeri sp. nov. shows some similarities to P. zardoyai (Fig. 11I) and to Continuconus estivali (Moolenbeek \& Richard, 1995) (Fig. 11J). The scarce specimens available of the latter species come from the Chesterfield Reef area. C. estivali is also characterized by its small size and conical shape. However, the pattern of $C$. estivali is quite constant and consists of 6 to 8 fine brown spiral lines on a white background. The shoulder in C. estivali is sharply angulated to carinate instead of angulated, and the teleoconch whorls on its stepped spire are concave. P. barazeri sp. nov. lacks the large, globose protoconch of about 2 whorls, which constitutes one of the most relevant features of $C$. estivali. The species $P$. zardoyai, recently described from Grand Passage, North New Caledonia, has a similar size and ground colour, with a variable pattern. However, its shell usually has a higher spire ( $\mathrm{RSH}=0.14-0.23$ versus $0.11-0.19$ for barazeri) of sigmoid profile rather than straight. Although their radular teeth look superficially similar, the tooth of $P$. barazeri sp. nov. (Fig. $11 \mathrm{~K})$ has a larger relative size $\left(\mathrm{S}_{\mathrm{L}} / \mathrm{T}_{\mathrm{L}}=26-30\right.$ versus $33-40$ for zardoyai) and bears more denticles in the laterally widened external cusp (7-9 in barazeri sp. nov. versus 5-6 in zardoyai). P. zardoyai and P. barazeri sp. nov. are phylogenetically distant (Fig. 5).

\section{Profundiconus puillandrei sp. nov. urn:Isid:zoobank.org:act:55807BF8-D984-42C1-B039-F3EBD8EB2C13} Figs $12 \mathrm{~A}-\mathrm{J}, 13 \mathrm{~A}-\mathrm{D}, 14$

Conus ikedai - Poppe 2008: pl. 615, fig. 1a-b (non C. ikedai Ninomiya, 1987).

Conus smirna - Marshall 1981: 499, fig. 3j (non C. smirna Bartsch \& Rehder, 1943).

Conus sp. C - Röckel et al. 1995b: 585, fig. 49.

Profundiconus n. sp. g. - Puillandre et al. 2014: Supplementary Material 1 (unfigured).

\section{Etymology}

This new species is dedicated to Dr. Nicolas Puillandre, mollusc curator at the MNHN. Dr. Puillandre has a long and outstanding trajectory in the study of the phylogeny of the Conoidea. The naming of the new species after him recognises his important contributions to the taxonomy of Conoidea at the molecular level.

\section{Type material examined}

\section{Holotype}

NEW CALEDONIA: $43.2 \times 18.0$ mm, R/V Alis, NORFOLK 1 Expedition, st. DW 1707, Banc Jumeau Est, Norfolk Ridge, $23^{\circ} 43^{\prime}$ S, $168^{\circ} 16^{\prime}$ E, 381-493 m (MNHN IM-2000-30771; Fig. 12A).

\section{Paratypes}

NEW CALEDONIA: $39.6 \times 17.3 \mathrm{~mm}$, R/V Alis, NORFOLK 2 Expedition, st. DW 2072, Banc Aramis, Norfolk Ridge, 2521' S, 16857' E, 1000-1006 m (MNHN IM-2000-30772; paratype 1; Fig. 12B); 
$40.7 \times 16.8 \mathrm{~mm}, \mathrm{R} / \mathrm{V}$ Alis, NORFOLK 2 Expedtion, st. DW 2077, Banc Zorro, Norfolk Ridge, $25^{\circ} 21^{\prime} \mathrm{S}$, 168 19' E, 666-1000 m (MNHN IM-2000-30773; paratype 2; Fig. 12C); $35.0 \times 15.5 \mathrm{~mm}$, R/V Alis, NORFOLK 2 Expedition, st. DW 2068, Banc Porthos, Norfolk Ridge, 2520' S, 16857' E, 680-980 m (MNHN IM-2000-30774; paratype 3; Fig. 12D); $31.7 \times 13.2 \mathrm{~mm}$, R/V Alis, NORFOLK 2 Expedition,

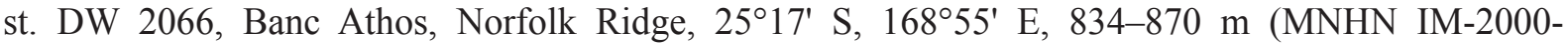
30775; paratype 4; Fig. 12E, H); $43.6 \times 18.1 \mathrm{~mm}$, R/V Alis, NORFOLK 2 Expedition, st. DW 2074,

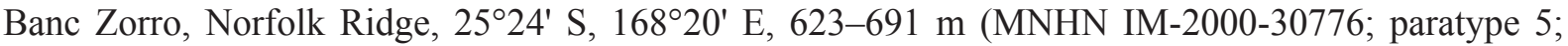
Fig. 12F); $57.3 \times 24.6 \mathrm{~mm}$, R/V Alis, EXBODI Expedition, st. DW 3907, Récifs de l'Astrolabe-Nord Ouest, 1950' S, 165³3' E, 608-671 m (MNHN IM-2009-31320; paratype 6; Fig. 12G; GenBank accession number (coxl sequence): KT874752); $45.2 \times 18.5 \mathrm{~mm}, \mathrm{R} / \mathrm{V}$ Alis, NORFOLK 2 Expedition, st. DW 2054, Banc Jumeau Est, Norfolk Ridge, 2340' S, 168 $15^{\prime}$ E, 736-800 m (MNHN IM-200030778; paratype 7; Fig. 12I); $44.8 \times 18.2 \mathrm{~mm}$, R/V Alis, BATHUS 3 Expedition, st. DW 776, Loyalty Ridge, 244ㄴ' S, $170^{\circ} 08^{\prime}$ E, 770-830 m (MNHN IM-2000-30779; paratype 10); $49.9 \times 21.6 \mathrm{~mm}$, R/V Alis, TERRASSES Expedition, st. DW 3045, Mont J, Ride des Loyautés, 2348' S, 16946' E, 660710 m (MNHN IM-2009-18221; paratype 11; GenBank accession number (coxl sequence): KJ550484); $37.0 \times 17.2 \mathrm{~mm}, \mathrm{R} / \mathrm{V}$ Alis, BATHUS 3 Expedition, st. DW 776, Loyalty Ridge, 244' S, $170^{\circ} 08^{\prime} \mathrm{E}$, 770-830 m (MNCN 15.05/60171; paratype 12).

NEW ZEALAND: $38.9 \times 17.5$ mm, R/V Tangaroa, st. K861, Kermadec Ridge, 30³6.5' S, $178^{\circ} 22.5^{\prime}$ W, $1030 \mathrm{~m}$ (NIWA 99587; paratype 8; Fig. 12J); $44.9 \times 19.5$ mm, R/V Tangaroa, st. K831, Kermadec Ridge, $29^{\circ} 51.5^{\prime} \mathrm{S}, 178^{\circ} 10.5^{\prime} \mathrm{W}, 965$ m (NIWA 99588; paratype 9).

\section{Type locality}

NEW CALEDONIA: Banc Jumeau Est, Norfolk Ridge, 381-493 m, 23ํํ' S, 168¹6' E (NORFOLK 1 st. DW1707).

\section{Other material examined}

NEW CALEDONIA: $33.2 \times 14.8$ mm, R/V “Alis”, NORFOLK 2 Expedition, st. DW 2057, Banc Introuvable, Norfolk Ridge, 244ㅇ' S, 168³9' E, 555-565 m (MNHN IM-2007-34865; GenBank accession number (coxl sequence): KJ550262). Note: This specimen, matching the holotype, was photographed (http://coldb.mnhn.fr/catalognumber/mnhn/im/2007-34865) and sequenced, but the shell was destroyed in the process and is no longer available.

Additionally, we examined 31 more specimens from 15 uncataloged MNHN lots collected at several stations in Norfolk Ridge and Loyalty Ridge, New Caledonia, by the R/V "Alis" in the course of several campaigns. Several specimens of shells in private collections collected in Balut Is., Philippines at 100$150 \mathrm{~m}$, showing the conchological features of Profundiconus puillandrei sp. nov., were also examined.

\section{Description}

Morphometric parameters: $\mathrm{S}_{\mathrm{L}}=29-57 \mathrm{~mm} ; \mathrm{RD}=0.53-0.62 ; \mathrm{RSH}=0.22-0.29 ; \mathrm{PMD}=0.81-0.90$.

Shell moderately small to medium sized (maximum length $57.0 \mathrm{~mm}$ ). Shell profile ventricosely conical, with high spire. Spire profile sigmoid to slightly concave. Protoconch multispiral, with 3-3.5 whorls, white to yellow-brown. Last whorl of larval shell shows minute axial ridges. Early teleoconch whorls with nodules which are often indistinct after whorls 5 to 6 , but may persist, forming nodulose ridge reaching shoulder on last whorl. Sutural ramp flat to slightly concave, with very fine striae and arcuate threads becoming obsolete in late whorls. Shoulder with distinct ridge, usually smooth, although nodulose or even strongly nodulose in some specimens. Last whorl with convex sides adapically, then almost straight and slightly concave abapically. Last whorl smooth or with very fine striae becoming more evident 


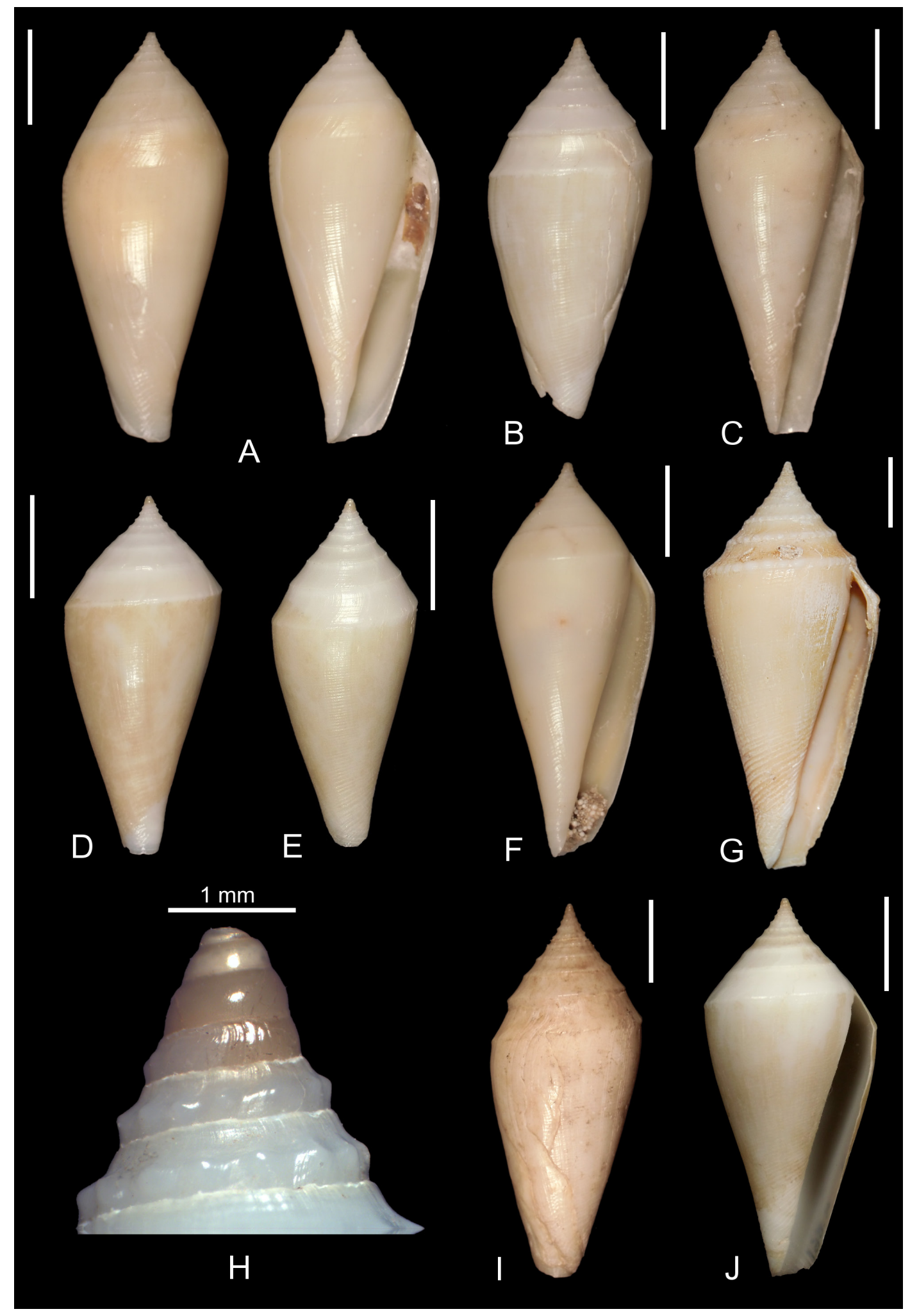

Fig. 12. Profundiconus puillandrei sp. nov. A. Holotype, $43.2 \times 18.0 \mathrm{~mm}$. B. Paratype $1,39.6 \times 17.3 \mathrm{~mm}$. C. Paratype 2, $40.7 \times 16.8 \mathrm{~mm}$. D. Paratype 3, $35.0 \times 15.5 \mathrm{~mm}$. E. Paratype 4, $43.6 \times 18.1 \mathrm{~mm}$. F. Paratype 5, $43.6 \times 18.1 \mathrm{~mm}$. G. Paratype $6,57.3 \times 24.6 \mathrm{~mm}$. H. Paratype 4, enlargement of the spire. I. Paratype 7, $45.2 \times 18.5 \mathrm{~mm}$. J. Paratype $8,38.9 \times 17.5 \mathrm{~mm}$. Scale bars $=10 \mathrm{~mm}$ unless otherwise indicated. 
towards base. Spire and last whorl patternless, white to pale straw-yellow in colour. Columella white. Aperture pale yellow or white. Periostracum yellow, thin and translucent. Operculum with serrations.

Radular tooth examined in holotype (Fig. 13A), in paratypes 3 (Fig. 13B-D), 6 and 9, and in an additional non-type specimen. 48 to 62 teeth in radular sac. Radular tooth small for size of shell: its total length relative to shell length $S_{L} / T_{L}=75-105$. Anterior portion shorter than posterior section of tooth $\left(\mathrm{T}_{\mathrm{L}} / \mathrm{AP}_{\mathrm{L}}=3.1-3.6\right)$. With one barb and pointed blade which covers $50-62 \%$ of anterior portion of tooth. External cusp present, extending between 64 and $90 \%$ of length of anterior portion of tooth. External cusp laterally widened and serrated, with 4-5 small denticles. Large adapical opening occupying most of anterior portion of tooth $\left(100 \mathrm{AO}_{\mathrm{L}} / \mathrm{AP}_{\mathrm{L}}=64-75\right)$. Fringe of closely spaced projections pointing towards apex immediately below waist. Shaft fold present. Large and prominent basal spur on top of slanted base of tooth.

\section{Distribution and habitat}

New Caledonia (Norfolk Ridge and Loyalty Ridge) and New Zealand (Kermadec Ridge), at depths from 380 to $1100 \mathrm{~m}$ (Fig. 14). Several empty shells matching P. puillandrei sp. nov. from Balut Is., Mindanao, Philippines, have been examined. The identity of these specimens from the Philippines

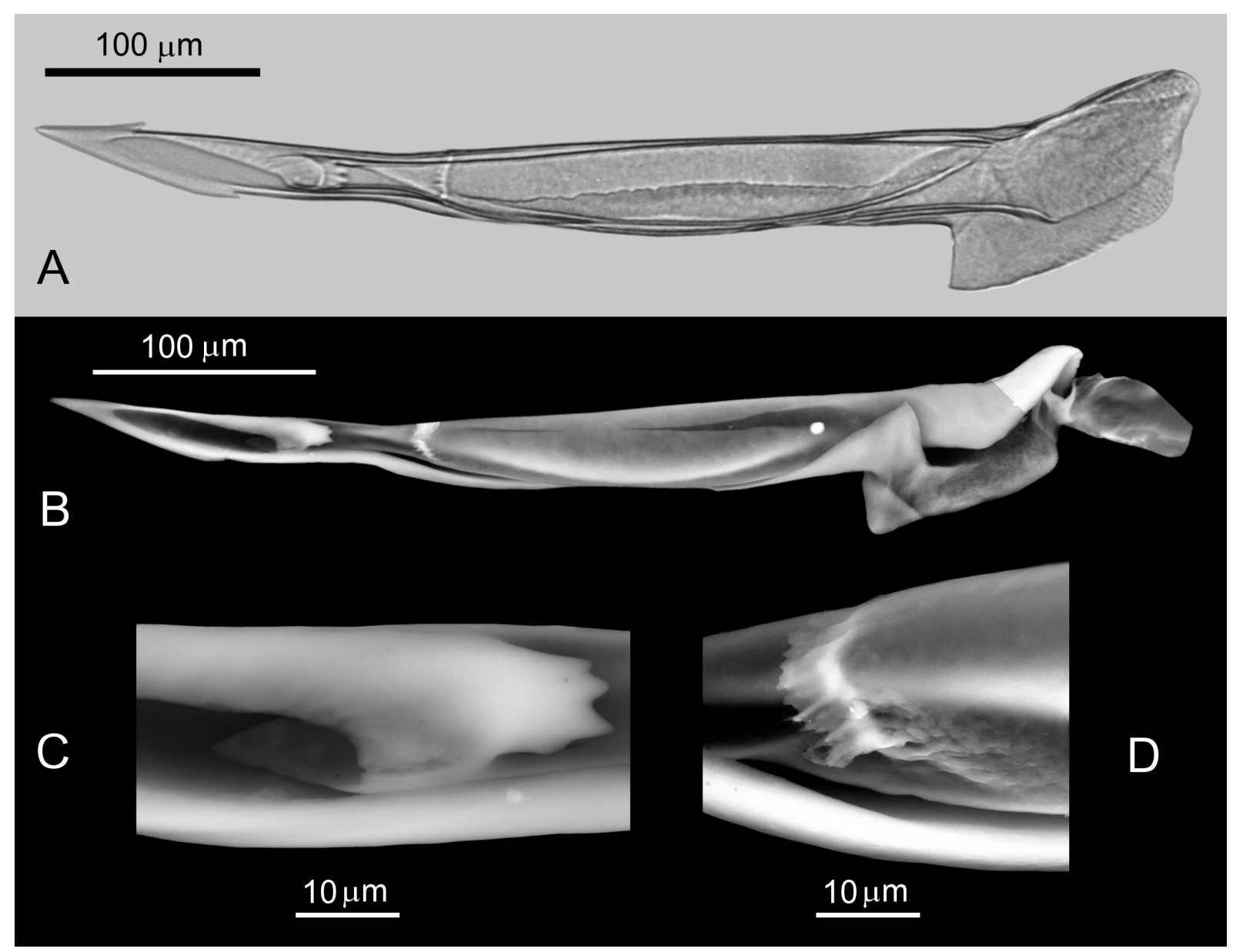

Fig. 13. Radular teeth extracted from Profundiconus puillandrei sp. nov. A. Optical photomicrograph (holotype, MNHN IM-2000-30771, S $43.2 \mathrm{~mm}$ ). B. SEM photomicrograph (paratype 3, MNHN IM2000-30774, $\mathrm{S}_{\mathrm{L}} 35.0 \mathrm{~mm}$ ). C. Enlargement of the external cusp. D. Enlargement of the middle section of B. 
(allocated in several private collections) could not be confirmed by radular or molecular studies, but the conchological features seem consistent with the identification of these specimens (often labelled as Conus cf. ikedai, or Conus darkini "albinistic") as P. puillandrei sp. nov. This is a feasible possibility given the multispiral protoconch of this species (suggesting a planktonic larval development), and might represent a significant range extension to the Philippines.

\section{Remarks}

Profundiconus puillandrei sp. nov. has been dredged alive from 1030-1180 m offCurtis Island, Kermadec Ridge, New Zealand (identified as Conus smirna; see Marshall 1981). This observation makes this species one of the deepest-living ones among the known cone snails. P. puillandrei sp. nov. was initially identified as "giant" P. vaubani (Fig. 1I). Apart from being smaller in size, P. vaubani has a paucispiral protoconch of 1.75 whorls and a ridge at the shoulder with axial costae, which are absent in the case of $P$. puillandrei sp. nov. The shell pattern of $P$. vaubani consists of light brown axial streaks from base to spire, whereas the shell of $P$. puillandrei sp. nov. is patternless. The radular teeth of $P$. vaubani (Fig. 2A-C) and P. puillandrei sp. nov. (Fig. 13) are superficially similar, but the tooth of P. vaubani has a much larger relative size, with $\mathrm{S}_{\mathrm{L}} / \mathrm{T}_{\mathrm{L}}=27-31$ compared to $75-105$ for $P$. puillandrei sp. nov. The new species can also be compared with P. profundorum (Fig. 1A, L) and P. smirnoides (Fig. 1D). Like P. puillandrei sp. nov, these two species have multispiral protoconchs. There are no significant differences in shell shape among these species: ANCOVA for MD, HMD and $\mathrm{SH}$, using species hypothesis as a factor and $\mathrm{S}_{\mathrm{L}}$ as covariate, did not yield statistically significant results. However, they differ significantly in average shell length: puillandrei $\mathrm{S}_{\mathrm{L}} 39.82 \mathrm{~mm}$, profundorum $\mathrm{S}_{\mathrm{L}} 96.93 \mathrm{~mm}(\mathrm{t}=10.28, \mathrm{p}=2.13 \times$ $\left.10^{-12} ; \mathrm{U}=0, \mathrm{p}=5.15 \times 10^{-7}\right)$, smirnoides $\mathrm{S}_{\mathrm{L}} 76.09 \mathrm{~mm}\left(\mathrm{t}=-10.20, \mathrm{p}=5.25 \times 10^{-10} ; \mathrm{U}=0, \mathrm{p}=2.5 \times 10^{-5}\right)$.

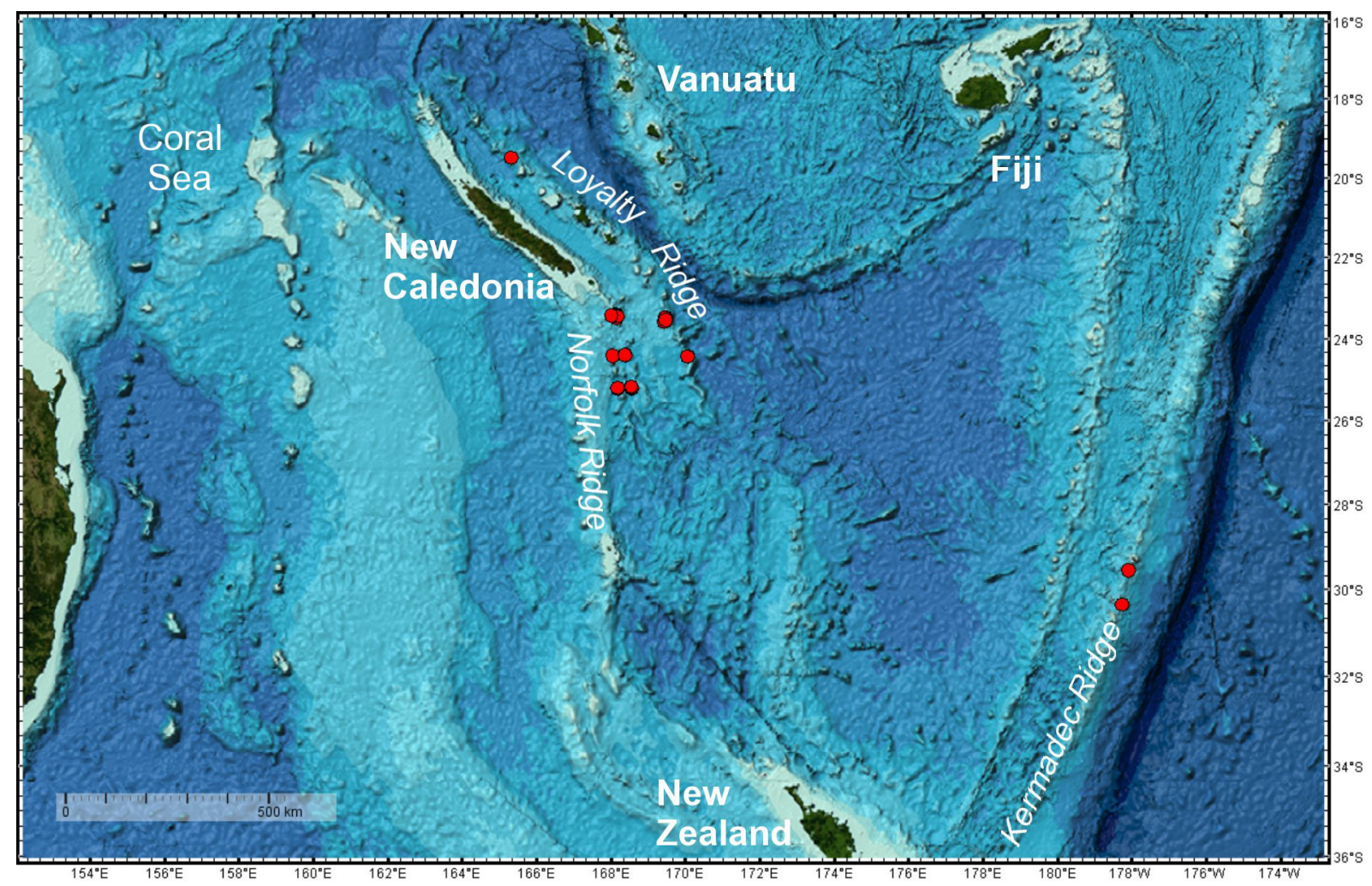

Fig. 14. Distribution map for Profundiconus puillandrei sp. nov. Red circles indicate the points where the species has been collected. 
The shell of P. puillandrei sp. nov. has a distinct shoulder ridge, usually smooth but some times nodulose, which is absent in $P$. profundorum and less developed and always smooth in P. smirnoides. The shell of P. puillandrei sp. nov. is patternless, whereas both P. profundorum and $P$. smirnoides exhibit a characteristic pattern of broad, pale brown spiral bands on each side of centre, often interrupted by creamy white axial streaks in the case of $P$. smirnoides. The morphology of the radular tooth of $P$. puillandrei sp. nov. (Fig. 13) and of P. smirnoides (Fig. 9H) is very different. The radular tooth of P. profundorum is unknown, preventing its comparison with the tooth of $P$. puillandrei sp. nov.

Most of the shells of P. puillandrei sp. nov. examined were not nodulose at the shoulder ridge (Fig. 12). About $10 \%$ of the specimens studied had a nodulose spire and shoulder ridge (i.e., paratype 6, Fig. 12G), coming mainly from Loyalty Ridge. These include two of the sequenced individuals, which, however, were genetically similar to the ones with a smooth ridge. Moreover, nodulose and non-nodulose specimens exhibit analogous radular and protoconch morphology. The presence of nodules at the spire and shoulder causes an apparent difference in shape, which is possibly the main source of intraspecific phenotypic variability within this species. Nodulose specimens may resemble a small $P$. teramachii (e.g., paratype 6, Fig. 12G), a distinct but related species as inferred from the tree in Fig. 5. The shell of P. teramachii is also patternless and has a ground colour and protoconch morphology similar to that of P. puillandrei sp. nov. The radular tooth of $P$. teramachii (Fig. 2D-F) is also similar to that of $P$. puillandrei sp. nov. (Fig. 13). However, P. teramachii attains a larger size $\left(\mathrm{S}_{\mathrm{L}}=55-111 \mathrm{~mm}\right)$, has a lower spire (RSH $0.11-0.22$ versus $0.22-0.29$ in P. puillandrei sp. nov.) and usually exhibits a broadly carinate shoulder. P. puillandrei sp. nov. is phylogenetically related to P. neotorquatus stat. nov., P. neocaledonicus sp. nov., P.teramachii and $P$. smirnoides.

Profundiconus neocaledonicus sp. nov. urn:1sid:zoobank.org:act:6581A3CA-DA2E-44A2-8E6E-2600CCA3B1D3

Figs $15 \mathrm{~A}-\mathrm{J}, 16 \mathrm{~A}-\mathrm{C}, 17$

Conus profundorum - Rolan \& Raybaudi-Massilia 1994: 33, pl. 11, fig. 82 (non Chelyconus (Profundiconus) profundorum Kuroda, 1956). — Röckel et al. 1995a: 381, pl. 27, fig. 16. — Röckel et al. 1995b: 563, fig. 22.

Profundiconus cf. profundorum - Puillandre et al. 2014: Supplementary Material 1 (unfigured).

\section{Etymology}

The epithet of this species makes reference to its distribution in deep water around New Caledonia.

\section{Type material examined}

\section{Holotype}

NEW CALEDONIA: $45.9 \times 21.7 \mathrm{~mm}, \mathrm{R} / \mathrm{V}$ Alis, TERRASSES Expedition, st. DW 3076, Banc Crypthélia, Norfolk Ridge, 23ํ1'12" S, 168¹3'18" E, 390-570 m (MNHN IM-2009-18227; Fig. 15A; GenBank accession number (coxl sequence): KJ550428).

\section{Paratypes}

NEW CALEDONIA: $61.3 \times 28.1 \mathrm{~mm}$, R/V Alis, EXBODI Expedition, st. DW 3889, Mont Vauban Partie SE, $22^{\circ} 25^{\prime} \mathrm{S}, 171^{\circ} 41^{\prime}$ E, $350 \mathrm{~m}$ (MNHN 2009-31323; paratype 1; Fig. 15B); $52.6 \times 24.7 \mathrm{~mm}$, R/V Alis, SMIB 8 Expedition, st. DW 167, Norfolk Ridge, 233' S, 16743' E, 430-452 m (MNHN IM-2000-30780; paratype 2; Fig. 15C); $46.7 \times 20.4$ mm, R/V Alis, TERRASSES Expedition, st. DW

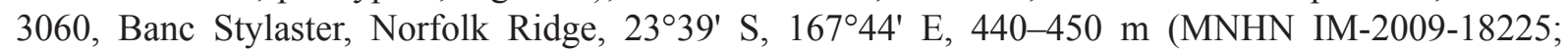
paratype 3; Fig 15G; GenBank accession number (coxl sequence): KJ550427); $71.8 \times 37.0 \mathrm{~mm}$, R/V Coriolis, CHALCAL 2 Expedition, st. DW 82, S New Caledonia, 23ำ $14^{\prime}$ S, 168 ${ }^{\circ} 04^{\prime}$ E, $304 \mathrm{~m}$ (MNHN IM-2000-30782; paratype 4; Fig. 15D); $92.0 \times 42.0$ mm, R/V Alis, NORFOLK 1 Expedition, 


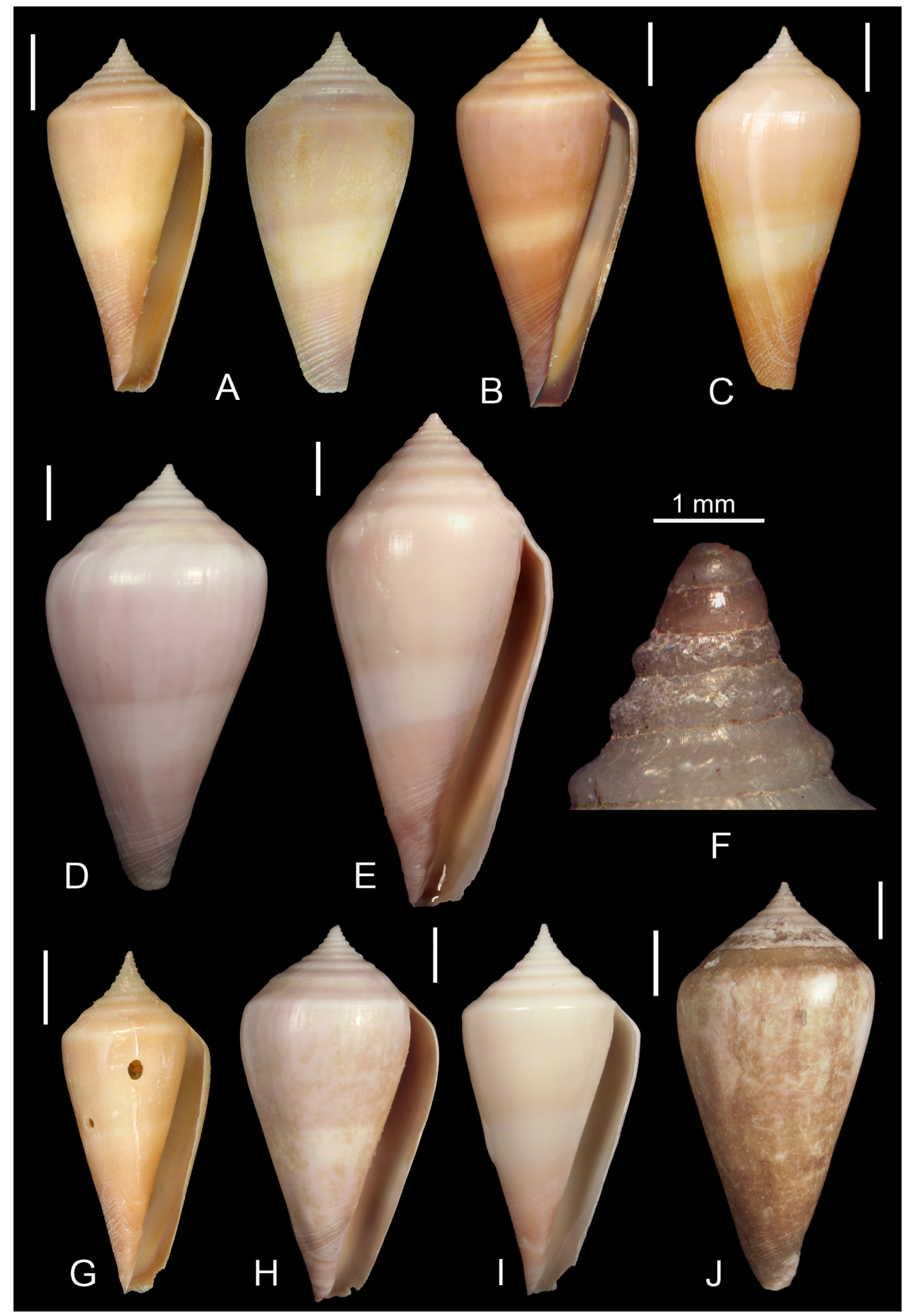

Fig. 15. Profundiconus neocaledonicus sp. nov. A. Holotype, $45.9 \times 21.7 \mathrm{~mm}$. B. Paratype $1,61.3 \times$ $28.1 \mathrm{~mm}$. C. Paratype 2, 52.6 $\times 24.7 \mathrm{~mm}$. D. Paratype 4, 71.8 $\times 37.0 \mathrm{~mm}$. E. Paratype 5, $92.0 \times 42.0 \mathrm{~mm}$. F. Paratype 1, enlargement of the spire. G. Paratype 3, $46.7 \times 20.4 \mathrm{~mm}$. H. Paratype $6,40.0 \times 16.8 \mathrm{~mm}$. I. Paratype 7, $54.5 \times 25.4 \mathrm{~mm}$. J. Paratype $8,67.3 \times 33.0 \mathrm{~mm}$. Scale bars $=1 \mathrm{~mm}$ unless otherwise indicated. 
st. DW 1732, Banc P, Norfolk Ridge, 2320' S, $168^{\circ} 16^{\prime}$ E, 347-1063 m (MNHN IM-2000-30783; paratype 5; Fig. 15E); $65.1 \times 32.5 \mathrm{~mm}$, R/V Alis, MUSORSTOM 6 Expedition, st. DW 406, Loyalty Ridge, $20^{\circ} 41^{\prime} \mathrm{S}, 16^{\circ} 07^{\prime} \mathrm{E}, 373 \mathrm{~m}$ (MNHN IM-2000-30784; paratype 6; Fig. 15H); $54.5 \times 25.4 \mathrm{~mm}$, R/V Coriolis, CHALCAL 2 Expedition, st. CC1, S New Caledonia, 245' S, 168²2' E, $500 \mathrm{~m}$ (MNHN IM-2000-30785; paratype 7; Fig. 15I); $67.3 \times 33.0$ mm, R/V Alis, NORFOLK 1 Expedition, st. DW 1657, Banc N, Norfolk Ridge, 2328' S, 16752' E, 305-332 m (MNHN IM-2000-30786; paratype 8; Fig. 15J); $61.5 \times 28.7 \mathrm{~mm}$, R/V Alis, NORFOLK 1 Expedition, st. DW 1658, Banc N, Norfolk Ridge, $23^{\circ} 26^{\prime}$ S, $167^{\circ} 50^{\prime}$ E, 320-336 m (MNHN IM-2000-30787; paratype 9); $65.5 \times 35.7 \mathrm{~mm}$,

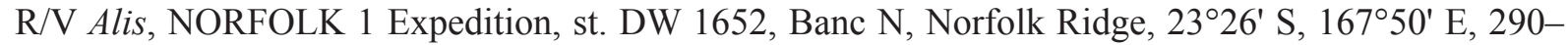
378 m (MNHN IM-2000-30788; paratype 10); $53.4 \times 22.8$ mm, R/V Alis, BATHUS 3 Expedition, st. CP

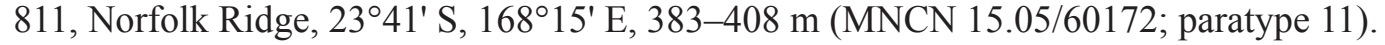

\section{Type locality}

NEW CALEDONIA: Banc Crypthélia, Norfolk Ridge, 23ำ $14^{\prime} \mathrm{S}, 168^{\circ} 13^{\prime} \mathrm{E}, 390-570$ m (TERRASSES Expedition st. DW3076).

\section{Other material examined}

NEW CALEDONIA: $39.9 \times 18.8 \mathrm{~mm}$, R/V Alis, NORFOLK 2 Expedition, st. DW 2156, Ile des Pins, $22^{\circ} 54^{\prime}$ S, $167^{\circ} 15^{\prime}$ E, 468-500 m (MNHN IM-2007-34866; GenBank accession number (coxl sequence):
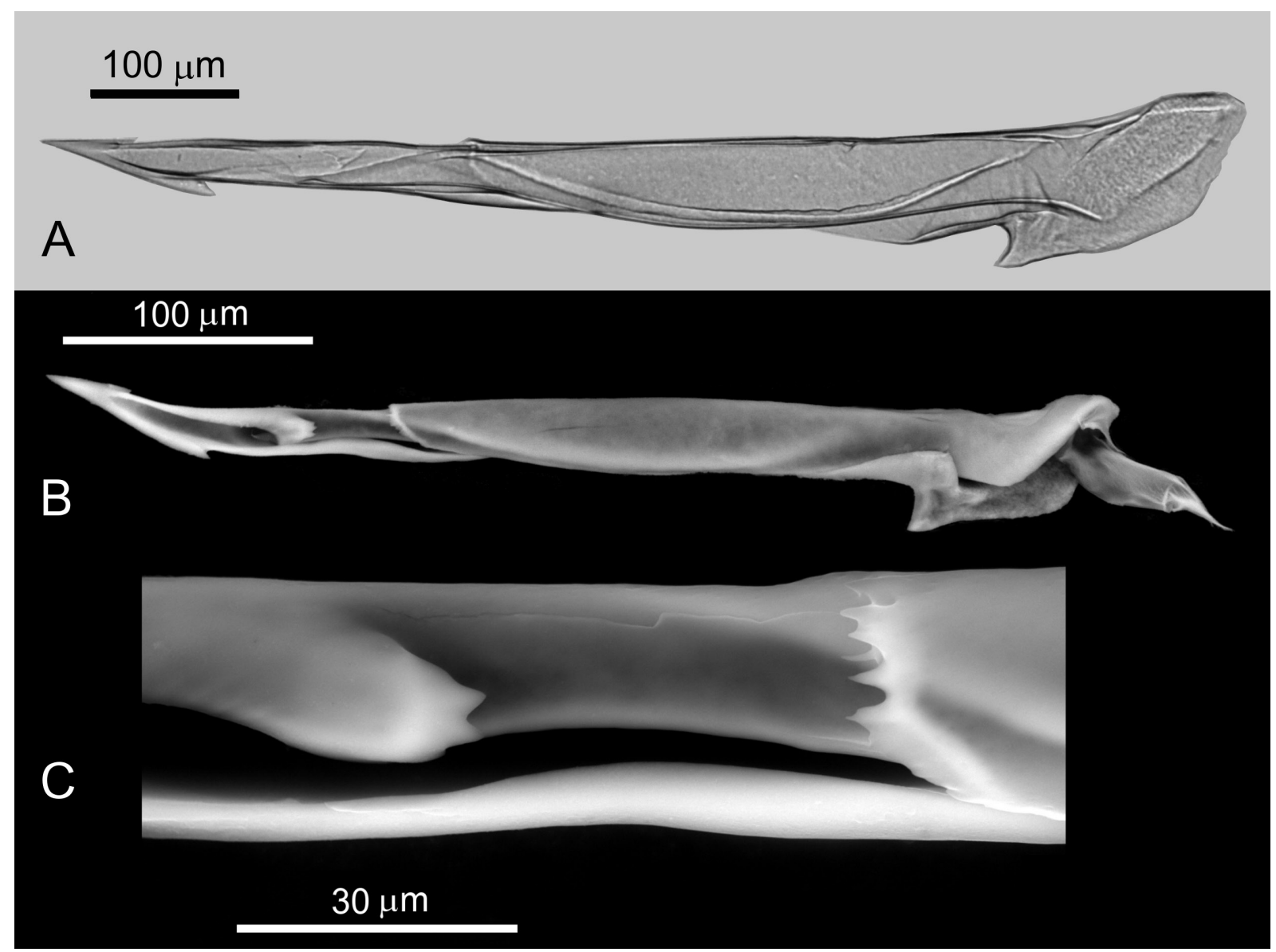

Fig. 16. Radular teeth extracted from Profundiconus neocaledonicus sp. nov. A. Optical photomicrograph (paratype 1, MNHN IM-2009-31323, S $61.3 \mathrm{~mm}$ ). B. SEM photomicrograph (paratype 7, MNHN IM2000-30785, $\left.\mathrm{S}_{\mathrm{L}} 54.5 \mathrm{~mm}\right)$. C. Enlargement of the middle section of B. 
KJ550426). This specimen was databased (http://coldb.mnhn.fr/catalognumber/mnhn/im/2007-34866) and sequenced, but the shell was destroyed in the process and is no longer available.

Additionally, we examined 32 more specimens from 18 uncataloged MNHN lots collected at several stations in Norfolk Ridge and Loyalty Ridge, New Caledonia, in the course of several campaigns.

\section{Description}

Morphometric parameters: $\mathrm{S}_{\mathrm{L}}=45-80 \mathrm{~mm} ; \mathrm{RD}=0.54-0.66 ; \mathrm{RSH}=0.16-0.22 ; \mathrm{PMD}=0.81-0.92$.

Medium-sized to moderately large (maximum length $92.0 \mathrm{~mm}$ ). Shell profile ventricosely conical to conical, with rounded shoulder and spire low to moderately high. Spire profile sigmoid, occasionally slightly concave. Protoconch multispiral of 3 or more whorls, white to pale violet-brown (Fig. 15F). First 4-7 postnuclear whorls nodulose. Teleoconch sutural ramp flat, slightly concave or sigmoid in later whorls, smooth, with cords absent. Last whorl smooth, with fine spiral ribs at base. Ground colour creamy-white to cream. Last whorl with two broad violet-brown, light brown or tan spiral bands above and below midbody, which exhibits broad ground-coloured spiral band. Colour is darker towards base, usually purplish. Narrow ground-colour spiral band often present at height of shoulder. Spire patternless, of ground colour, occasionally showing diffuse pale violet-brown or light brown on top of teleoconch whorls. Aperture light to pinkish brown. Periostracum olive, thin, translucent, smooth. Operculum with lateral serrations.

Radular tooth examined in paratypes 1 (Fig. 16A), 2 and 7 (Fig. 16B, C). 34-45 teeth in radular sac. Radular tooth of rather small relative size: its total length relative to shell length $\mathrm{S}_{\mathrm{L}} / \mathrm{T}_{\mathrm{L}}=61-87$. Anterior portion shorter than posterior section of tooth $\left(\mathrm{T}_{\mathrm{L}} / \mathrm{AP}_{\mathrm{L}}=3.1-3.4\right)$. With one barb and pointed, prominent

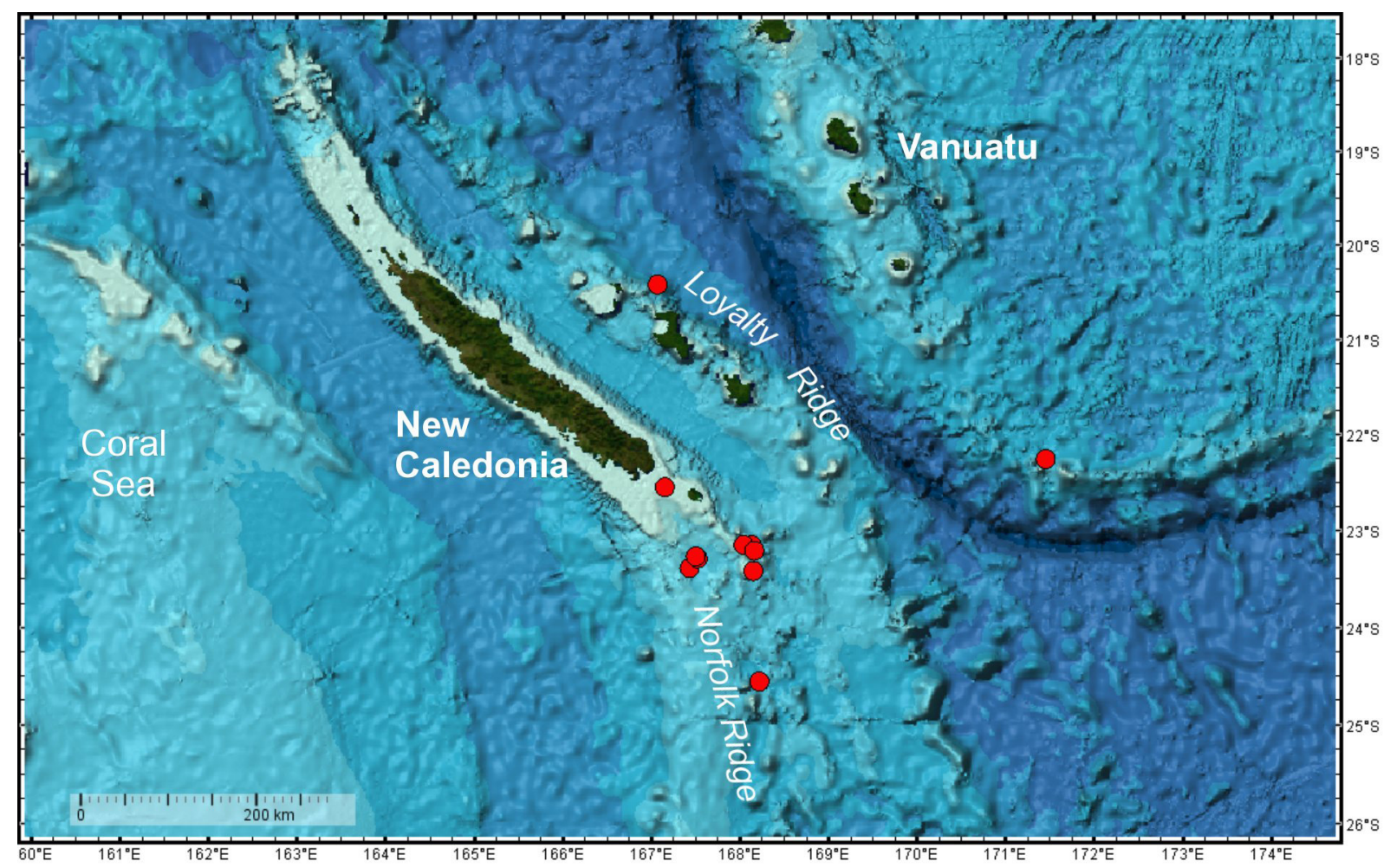

Fig. 17. Distribution map for Profundiconus neocaledonicus sp. nov. Red circles indicate the points where the species has been collected. 
Table 3. Comparison between morphometric parameters for P. neocaledonicus sp. nov. $(\mathrm{N}=28)$ and P. profundorum (Kuroda, 1956) $(\mathrm{N}=26)$ : Least-squares means and ANCOVA results.

\begin{tabular}{|c|c|c|c|c|}
\hline \multirow[t]{2}{*}{ Trait } & \multicolumn{2}{|c|}{ LS mean values $(\mathrm{mm})$} & \multirow[t]{2}{*}{$\mathbf{F}$} & \multirow[t]{2}{*}{$\mathbf{p}$} \\
\hline & P. neocaledonicus (New Caledonia) & P. profundorum (Japan/China) & & \\
\hline MD & 36.4 & 33.2 & 12.59 & 0.0008 \\
\hline HMD & 51.7 & 49.8 & 5.77 & 0.02 \\
\hline SH & 15.3 & 17.4 & 7.74 & 0.0075 \\
\hline $\mathrm{S}_{\mathrm{L}}{ }^{1}$ & 57.0 & 96.9 & - & - \\
\hline
\end{tabular}

${ }^{1}$ For the pairwise comparison of mean $\mathrm{S}_{\mathrm{L}}: \mathrm{t}=-8.82, \mathrm{p}=6.63 \times 10^{-12} ; \mathrm{U}=692, \mathrm{p}=1.43 \times 10^{-8}$.

blade which covers $43-54 \%$ of apical portion of tooth. External cusp present, extending between 65 and $88 \%$ of length of anterior portion of tooth. External cusp not much widened laterally and serrations can be indistinct, with only $0-3$ small blunt denticles. Large adapical opening occupying most of anterior portion of tooth $\left(100 \mathrm{AO}_{\mathrm{L}} / \mathrm{AP}_{\mathrm{L}}=62-75\right)$. With characteristic fringe of closely spaced projections pointing towards the apex located immediately below waist (Fig. 16C). Shaft fold present. Large and prominent basal spur on top of slanted base of tooth.

\section{Distribution and habitat}

Norfolk Ridge and Loyalty Ridge, New Caledonia, at depths from 290 to 1100 m (Fig. 17). A couple of empty shells resembling P. neocaledonicus sp. nov. from Aliguay Island, Philippines, have been examined. The identity of these specimens from the Philippines (coming from the John K. Tucker collection, now with the INHS, Illinois, USA) could not be confirmed by radular or molecular studies. This observation might suggest an extension of the distribution range to the Philippines, but would require additional substantiation.

\section{Remarks}

Profundiconus neocaledonicus sp. nov. has long been considered a local form of $P$. profundorum from New Caledonia (Röckel et al. 1995a). P. profundorum was originally described based upon material from Japan (type locality: "Off Tosa, Japan; 100+ fathoms") (Fig. 1A). In recent times, specimens of P. profundorum have become available from China (Fig. 1L). These specimens are characterised by their significantly larger mean shell length compared to the Japanese specimens (mean $\mathrm{S}_{\mathrm{L}}$ profundorum from Japan: $74.3 \mathrm{~mm}$; mean $\mathrm{S}_{\mathrm{L}}$ profundorum from China: $111.05 \mathrm{~mm} ; \mathrm{t}=13.12, \mathrm{p}=0 ; \mathrm{U}=0, p=0.000028$ ). Apart from differences in shell length, ANCOVA indicated no statistically significant differences between the morphometric parameters of $P$. profundorum from Japan and those from China (ANCOVA on $\mathrm{MD}: \mathrm{F}=1.94, \mathrm{p}=0.18$; on HMD $: \mathrm{F}=3.44, \mathrm{p}=0.08$; on $\mathrm{SH}: \mathrm{F}=0.05, \mathrm{p}=0.82$ ). Hence, we consider the Chinese and Japanese populations conspecific. Compared to P. profundorum, the shells of P. neocaledonicus sp. nov. from New Caledonia have a different shape, are consistently smaller in average shell length, and are also paler in colour. Table 3 shows the results of the ANCOVA with the morphometric shell parameters MD, HMD and SH as variables, and using species hypothesis as factor and $\mathrm{S}_{\mathrm{L}}$ as covariate. Least-squares means are listed, along with average shell lengths for each of the species.

These results confirm that the shell of $P$. neocaledonicus sp. nov. is significantly broader, more conical (higher HMD) and lower-spired than the shell of P. profundorum, which also has a larger mean $\mathrm{S}_{\mathrm{L}}$. A discriminant function analysis (DFA) using $\mathrm{MD}, \mathrm{HMD}, \mathrm{SH}$ and $\mathrm{S}_{\mathrm{L}}$ as variables and species hypothesis as factor correctly classified $94.4 \%$ of the specimens (all correct except two specimens of profundorum 
misclassified as neocaledonicus and one specimen of neocaledonicus misclassified as profundorum). A DFA excluding $\mathrm{S}_{\mathrm{L}}$ from the set of variables correctly classified $92.6 \%$ of the specimens (three profundorum were misclassified as neocaledonicus and one specimen of neocaledonicus misclassified as profundorum). These results indicate that $P$. neocaledonicus sp. nov. can be separated with a high degree of certainty from $P$. profundorum based on significant differences in size and shell shape. It was not possible to compare the radula of $P$. neocaledonicus sp. nov. with that of $P$. profundorum. The radular tooth morphology of $P$. profundorum is unknown, since all the published information (Rolán \& Raybaudi-Massilia 1994) actually corresponds to specimens from New Caledonia, here introduced as $P$. neocaledonicus sp. nov. No preserved specimens of $P$. profundorum from Chinese or Japanese localities were available for radular or molecular analyses.

Although the genetic differentiation of $P$. neocaledonicus sp. nov. from $P$. smirnoides and $P$. teramachii was not supported at the nodes on the tree in Fig. 5, P. neocaledonicus sp. nov. is easily separated from the sympatric species $P$. smirnoides based on shell and radular morphology. The shell of $P$. smirnoides (Fig. 1D) is significantly narrower, less conical and much more highly spired than that of $P$. neocaledonicus sp. nov. (ANCOVA with $\mathrm{S}_{\mathrm{L}}$ as covariate: on $\mathrm{MD}: \mathrm{F}=103.91, \mathrm{p}=0$; on $\mathrm{HMD}: \mathrm{F}=62.54, \mathrm{p}=0$; on $\mathrm{SH}: \mathrm{F}=28.37, \mathrm{p}=0)$. It also has a significantly larger mean shell length $(76.09 \mathrm{~mm}$ for smirnoides versus $57.03 \mathrm{~mm}$ for neocaledonicus, $\mathrm{t}=-4.299, \mathrm{p}=0.00011 ; \mathrm{U}=285.5, \mathrm{p}=0.00055$ ). P. smirnoides has a pattern of brown spiral bands on each side of centre interrupted by creamy white axial streaks, whereas in P. neocaledonicus sp. nov. is much simpler, consisting of pale purplish-brown broad bands on each side of centre on a creamy-white ground colour. Comparison of the large and elongated radular tooth of P. smirnoides (Fig. 9H) with that of P. neocaledonicus sp. nov. (Fig. 16) also allows the straightforward separation of the two species. P. teramachii (Fig. 1B) has a very different shell, larger in size, and is patternless, with a characteristic stepped spire and with a broadly carinated shoulder, sometimes with densely set rounded tubercles, particularly in smaller adults.

The species $P$. puillandrei sp. nov., which lives sympatrically with $P$. neocaledonicus sp. nov., has a significantly smaller shell length $(\mathrm{t}=4.296, \mathrm{p}=0.0001 ; \mathrm{U}=53, \mathrm{p}=0.000066)$, with differences in morphometric parameters that suggest that $P$. puillandrei sp. nov. has a narrower shell with a higher spire (ANCOVA with $\mathrm{S}_{\mathrm{L}}$ as covariate on $\mathrm{MD}: \mathrm{F}=6.23, \mathrm{p}=0.0168$; on $\mathrm{HMD}: \mathrm{F}=40.19, \mathrm{p}=0$; on $\mathrm{SH}: \mathrm{F}=35.46, \mathrm{p}=0$ ). This species shows a characteristic ridge at the shoulder, sometimes nodulose, whereas in P. neocaledonicus sp. nov. the shoulder is always rounded. The shell of P. puillandrei sp. nov. is patternless and does not exhibit the banding pattern visible in the shell of P. neocaledonicus sp. nov.

Röckel et al. (1995a: pl. 73, figs 17-18) illustrated one specimen identified as "Conus species no. 32". This specimen measures $50 \times 23 \mathrm{~mm}$ and comes from Nazca Ridge. Other specimens like the one illustrated in Röckel et al. (1995a) have been collected in deep-water on several seamounts across Sala y Gómez and Nazca Ridges in the course of several campaigns carried out by Russian research vessels in the 70's and 80's. The biota of the Nazca and Sala y Gómez submarine ridges was reviewed in Parin et al. (1997). The fauna of benthic and benthopelagic invertebrates of this area is much more closely related to the Indo-West Pacific than to the Eastern Pacific fauna and is characterized by a very high degree of endemism at the species level (51\% among identified bottom invertebrates). We have been unable to examine the specimens from the Nazca Ridge area, but the available photos (Röckel et al. 1995a) show a striking resemblance to the shells of $P$. neocaledonicus sp. nov. collected on Norfolk Ridge, New Caledonia, at a distance of $c .10500 \mathrm{~km}$ to the east. Further research might eventually prove their conspecificity, which would imply a considerable range extension for this species, or alternatively disclose a new species of Profundiconus most likely endemic to the Sala y Gómez and Nazca Ridge areas. 


\section{Discussion}

The BA and ML phylogenetic trees based on a subsample of the mitochondrial coxl dataset produced by Puillandre et al. (2014) plus new coxl sequences (supplied by N. Puillandre) confirmed with high statistical support that species in the genus Profundiconus form a monophyletic group. Profundiconus had already been elevated to the rank of genus by da Motta (1991) and Raybaudi-Massilia (1992). Tucker \& Tenorio (2009) placed this genus in the new family Conilithidae Tucker \& Tenorio, 2009 (type genus: Conilithes Swainson, 1840; type species: C. antidiluvianus (Bruguière, 1792), a Pliocene fossil species, Fig. 1E; see Janssen et al. 2014a, 2014b), along with other Holocene conid genera including Conasprella, Boucheticonus and Bathyconus (but not Cylinder Montfort, 1810 or Conus). Therefore, according to the tree in Fig. 5, the so-defined family Conilithidae would be polyphyletic. In order to reconcile taxonomy and phylogeny, the family Conilithidae would need to be restricted to the fossil genus Conilithes (Rolán \& Raybaudi-Massilia 1994) and Profundiconus if their morphological similarity is due to true synapomorphies, or alternatively Profundiconus would deserve its own family. The other living genera placed in Conilithidae by Tucker \& Tenorio (2009) and Tucker \& Tenorio (2013) would require placement in another suprageneric taxon, either family or subfamily, which would be sister group to the Conidae sensu Tucker \& Tenorio (2013) (the so-called "Large Major Clade" of Duda \& Kohn 2005, or the genus Conus sensu Puillandre et al. 2015). However, these taxonomic changes would require confirmation and support by more detailed molecular studies using additional gene markers, which allow for higher resolution of the reconstructed trees. Such studies and its taxonomic implications are beyond the scope of the present work, which is focused mainly on the characterization of genus Profundiconus as a whole.

The phylogenetic analyses of 55 specimens of Profundiconus showed individuals grouped in clades which do not correspond to any of the known species of Profundiconus. Such clades had already been recovered in the analysis by Puillandre et al. (2014) and were then labelled with letters, but the corresponding new taxa remained undescribed until now. Another two new species of Profundiconus, present in the tree in Fig. 5, were recently identified and described, namely P. zardoyai and P. smirnoides (Tenorio 2015a, 2015b). With all these recent additions and the new taxa included in the present work, the number of known living species of Profundiconus has been increased from 16 (Tucker \& Tenorio 2013 ) to 26 . This represents an increase of $62.5 \%$ in the total number of taxa existing in the genus and illustrates the potential for discovering new species of cone snails from the deep sea. We can anticipate that future surveys in deep waters across the Indo-West Pacific Ocean will yield Profundiconus species, many of which are expected to be new to science. Upon examination of the lots of material brought to the surface by research vessels, we can conclude that Profundiconus are one of the main components of the gastropod fauna at depths below $200 \mathrm{~m}$, and that species of this genus may attain very small adult sizes, so they can possibly remain overlooked or confused with juveniles of other species. Study of the conotoxins produced by individuals of Profundiconus is another field yet to be explored, with findings that are unpredictable, but hitherto exciting at the present moment. Unfortunately, the phylogenetic relationships among species within Profundiconus are poorly resolved. This could be due to either the lack of enough phylogenetic signal in the molecular marker at this taxonomic level, a rapid radiation event at the origin of the genus, or the extinction of different lineages during the evolutionary history of the group. This fact enhances the need for an integrative approach for species delimitation combining genetic, morphological and ecological data (Edwards \& Knowles 2014; Carstens et al. 2013), rather than relying on single locus genetic data only.

\section{Acknowledgements}

This work was partly supported by the Service de Systématique Moléculaire (UMS 2700 CNRS-MNHN) and by the CONOTAX Project, funded by the French "Agence Nationale de la Recherche" (grant number ANR-13-JSV7-0013-01). The material on which this paper is based has been accumulated during many 
expeditions of the Tropical Deep-Sea Benthos (ex MUSORSTOM) programme in the New Caledonia region and other localities around the world. We refer to Bouchet et al. (2008) for an overview of the programme and their acknowledgements to the captains, principal scientists and crews involved are applicable here. The phylogenetic analyses were performed on the MNHN cluster (UMS 2700 CNRS MNHN). Our most sincere thanks to: Prof. Philippe Bouchet and Virginie Héros, from the MNHN, Paris, for all the facilities they provided for our study of the deep-water cones from New Caledonia and the Solomon Islands; Dr. Nicolas Puillandre (MNHN, Paris) for kindly supplying additional coxl sequences and information, and for his useful insights; Barbara Buge, Julien Brisset, Laetitia AznarCormano and Caroline Walliang (all MNHN) for their help in curating the specimens and producing the molecular data; Mr Alberto Jorge García, from the MNCN-CSIC, Madrid, for assistance with SEM studies; to Mr John K. Tucker (Rantoul, Illinois), Prof. Rafael Zardoya (MNCN-CSIC, Madrid) and Mr Loïc Limpaläer (Haudivillers, France) for their valuable suggestions and constructive criticism made upon reading the manuscript. Special thanks to Sadie Mills (NIWA, Wellington, New Zealand), for providing useful information and the loan of deep-water samples taken in research campaigns of the New Zealand Oceanographic Institute. We also thank Mr Yuko Nagai and the Zoological Society of Japan, for allowing the reproduction of several figures from Zoological Magazine (Japan).

\section{References}

April L., Mayden R.L., Hanner R.H. \& Bernatchez L. 2011. Genetic calibration of species diversity among North America's freshwater fishes. Proceedings of the National Academy of Sciences 108 (26): 10602-10607. http://dx.doi.org/10.1073/pnas.1016437108

Bergh R. 1896. Beiträge zur Kenntniss der Coniden. Nova Acta der kaiserlichen LeopoldinischCarolinischen deutschen Akademie der Naturforscher 65: 69-214. Available from http:// biodiversitylibrary.org/page/12612272 [accessed 1 Jan. 2016]

Bouchet P., Héros V., Lozouet P. \& Maestrati P. 2008. A quater-century of deep-sea malacological exploration in the South and West Pacific: Where do we stand? How far to go? In: Héros V., Cowie R.H. \& Bouchet P. (eds) Tropical Deep-Sea Benthos 25: 9-40. Mémoires du Muséum national d'Histoire naturelle 196: Muséum national d'Histoire naturelle, Paris.

Bouchet P., Kantor Yu.I., Sysoev A. \& Puillandre N. 2011. A new operational classification of the Conoidea (Gastropoda). Journal of Molluscan Studies 77: 273-308. http://dx.doi.org/10.1093/mollus/ eyr017

Carstens B.C., Pelletier T.A., Reid N.M. \& Satler J.D. 2013. How to fail at species delimitation. Molecular Ecology 22: 4369-4383. http://dx.doi.org/10.1111/mec.12413

Castelin M., Puillandre N., Lozouet P., Sysoev A., Richer de Forges B. \& Samadi S. 2011. Molluskan species richness and endemism on New Caledonian seamounts: Are they enhanced compared to adjacent slopes? Deep-Sea Research I 58: 637-646. http://dx.doi.org/10.1016/j.dsr.2011.03.008

Chee S.Y. 2014. Limitations of cytochrome oxidase I for the barcoding of Neritidae (Mollusca: Gastropoda) as revealed by Bayesian analysis. Genetics and Molecular Research 14 (4): 5677-5684. http://dx.doi.org/10.4238/2015.May.25.20

da Motta A.J. 1991. A systematic classification of the gastropod family Conidae at the generic level. La Conchiglia, Supplement: 1-48.

Darriba D., Taboada G.L., Doallo R. \& Posada D. 2012. jModelTest 2: more models, new heuristics and parallel computing. Nature Methods 9 (8): 772-772. http://dx.doi.org/10.1038/nmeth.2109

Duda Jr. T.F. \& Kohn A.J. 2005. Species-level phylogeography and evolutionary history of the hyperdiverse marine gastropod genus Conus. Molecular Phylogenetics and Evolution 34: 257-272. http://dx.doi.org/10.1016/j.ympev.2004.09.012 
Edgar R.C. 2004. MUSCLE: multiple sequence alignment with high accuracy and high throughput. Nucleic Acids Research 32 (5): 1792-1797. Available from: http://www.ebi.ac.uk/Tools/msa/muscle/ [accessed 1793 March 2015]

Edwards D.L. \& Knowles L.L. 2014. Species detection and individual assignment in species delimitation: can integrative data increase efficacy? Procceedings of the Royal Society B 281: e20132765. http:// dx.doi.org/10.1098/rspb.2013.2765

Fedosov A.E. 2011. Five new species of the genus Lienardia (Conidae: Gastropoda) from the shallow waters of central Philippines. Ruthenica 21: 123-135. Available from http://www.ruthenica.com/ documents/Vol21_Fedosov_123-135.pdf [accessed 2 Jan. 2016]

Felsenstein J. 1985. Confidence limits on phylogenies: an approach using the bootstrap. Evolution 39 (4): 783-791.

Folmer O., Black M., Hoeh W., Lutz R. \& Vrijenhoek R. 1994. DNA primers for amplification of mitochondrial cytochrome c oxidase subunit I from diverse metazoan invertebrates. Molecular Marine Biology and Biotechnology 3 (5): 294-299.

Guindon S. \& Gascuel O. 2003. A simple, fast, and accurate algorithm to estimate large phylogenies by maximumlikelihood.SystematicBiology 52(5): 696-704.http://dx.doi.org/10.1080/10635150390235520

Hammer Ø., Harper D.A.T. \& Ryan P.D. 2001. PAST: Paleontological statistics software package for education and data analysis. Palaeontologia Electronica 4 (1): 1-9. Available from http://palaeoelectronica.org/2001 1/past/issue1 01.htm [accessed 2 Jan. 2016]

Huelsenbeck J.P. \& Ronquist F. 2001. MrBayes: a program for the Bayesian inference of phylogeny. Bioinformatics 17: 754-755. http://dx.doi.org/10.1093/bioinformatics/17.8.754

Janssen A.W., Janssen R., Tracey S., Vaessen L.M.B. \& van der Voort J. 2014a. History of a marine, Cainozoic gastropod taxon, Conus antidiluvianus Bruguière, 1792 and its nomenclatural implications. Cainozoic Research 14 (1): 73-90.

Janssen A.W., Janssen R., Tracey S., Vaessen L.M.B. \& van der Voort J. 2014b. Case 3668: Conus antidiluvianus Bruguière, 1792 (Mollusca, Gastropoda, CONIDAE): proposed conservation of prevailing usage of specific name by setting aside the unidentifiable lectotype and replacing it with a neotype. Bulletin of Zoological Nomenclature 71 (4): 223-229.

Knowles L.L. \& Carstens B.C. 2007. Delimiting species without monophyletic gene trees. Systematic Biology 56: 887-895. http://dx.doi.org/10.1080/10635150701701091

Kohn A.J., Nishi M. \& Pernet B. 1999. Snail spears and scimitars: a character analysis of Conus radular teeth. Journal of Molluscan Studies 65: 461-481. http://dx.doi.org/10.1093/mollus/65.4.461

Kosuge S. 1979. Description of new and rare cones from the Western Pacific (Conidae, Gastropoda). Bulletin of the Institute of Malacology of Tokyo 1 (2): 21-22.

Kosuge S. 1981. Notes on newly recorded species of the superfamily Conacea from Philippines with descriptions of new species of the genera Terebra, Conus and Glyphostoma. Bulletin of the Institute of Malacology of Tokyo 1 (6): 93-96.

Kuroda T. 1956. New species of the Conidae (Gastropoda). Venus 19 (1): 1-16.

Librado P. \& Rozas J. 2009. DnaSP v. 5: a software for comprehensive analysis of DNA polymorphism data. Bioinformatics 25: 1451-1452. http://dx.doi.org/10.1093/bioinformatics/btp187

Mengual X., Ståhls G., Vujić A. \& Marcos-García M.A. 2006. Integrative taxonomy of Iberian Merodon species (Diptera, Syrphidae). Zootaxa 1377: 1-26. 
Marshall B.A. 1981. New records of Conidae (Mollusca: Gastropoda) from the New Zealand region. New Zealand Journal of Zoology 8: 493-501.

McGuire J.A., Linkem C.W., Koo M.S., Hutchison D.W., Lappin A.K., Orange D.I., Lemos-Espinal J., Riddle B.R. \& Jaeger J.R. 2007. Mitochondrial introgression and incomplete lineage sorting through space and time: phylogenetics of crotaphytid lizards. Evolution 61 (12): 2879-2897. http://dx.doi. org/10.1111/j.1558-5646.2007.00239.x

Moolenbeek R.G., Röckel D. \& Bouchet P. 2008. New records and new species of cones from deeper water off Fiji (Mollusca, Gastropoda, Conidae). Vita Malacologica 6: 35-49.

Okutani T. 2000. Marine Mollusks in Japan. Tokai Univeristy Press, Minamiyana, Japan.

Parin N.V., Mironov A.N. \& Nesis K.N. 1997. Biology of the Nazca and Sala y Gómez submarine ridges, an outpost of the Indo-West Pacific fauna in the Eastern Pacific Ocean: Composition and distribution of the fauna, its communities and history. Advances in Marine Biology 32: 145-242. http://dx.doi. org/10.1016/S0065-2881(08)60017-6

Poppe G.T. 2008. Philippine Marine Mollusks, Vol. II. Conchbooks, Hackenheim, Germany.

Posada D. \& Buckley T.R. 2004. Model selection and model averaging in phylogenetics: advantages of Akaike information criterion and Bayesian approaches over likelihood ratio tests. Systematic Biology 53 (5): 793-808. http://dx.doi.org/10.1080/10635150490522304

Puillandre N., Kantor Yu.I., Sysoev A., Couloux A., Meyer C., Rawlings T., Todd J.A. \& Bouchet P. 2011. The dragon tamed? A molecular phylogeny of the Conoidea (Gastropoda). Journal of Molluscan Studies 77: 259-272. http://dx.doi.org/10.1093/mollus/eyr015

Puillandre N., Koua D., Favreau P., Olivera B.M., Stöcklin R. 2012. Molecular phylogeny, classification and evolution of conopeptides. Journal of Molecular Evolution 74: 297-309. http://dx.doi.org/10.1007/ $\underline{\mathrm{s} 00239-012-9507-2}$

Puillandre N., Bouchet P., Duda Jr. T.F., Kauferstein S., Kohn A.J., Olivera B.M., Watkins M. \& Meyer C. 2014. Molecular phylogeny and evolution of the cone snails (Gastropoda, Conoidea). Molecular Phylogenetics and Evolution 78: 290-303. http://dx.doi.org/10.1016/j.ympev.2014.05.023

Puillandre N., Duda T.F., Meyer C., Olivera B.M. \& Bouchet P. 2015. One, four or 100 genera? A new classification of the cone snails. Journal of Molluscan Studies 81: 1-23. http://dx.doi.org/10.1093/ $\underline{\text { mollus/eyu } 055}$

Rabiller M. \& Richard G. 2014. Conus (Gastropoda, Conidae) from offshore French Polynesia: Description of dredging from TARASOC expedition, with new records and new species. Xenophora Taxonomy 5: 25-49.

Rambaud A. \& Drummond A. 2007. Tracer, version 1.4. Available from http://beast.bio.ed.ac.uk/Tracer [accessed 17 Dec. 2015]

Raybaudi-Massilia G. 1992. Note sul genere Profundiconus (Kuroda, 1956) e descrizione di una nuova specie (Gastropoda: Conidae). La Conchiglia: International Shell Magazine 23 (263): 46-50.

Röckel D. 1994. Conus tuberculosus Tomlin, 1937, a disregarded Conus species. Argonauta 8 (7-12): $1-6$.

Röckel D., Korn W. \& Kohn A.J. 1995a. Manual of the Living Conidae, Volume 1: Indo-Pacific Region. Hemmen, Wiesbaden. Available from http://theconecollector.com/RKK/RKK Download.htm [accessed 17 Dec. 2015]

Röckel D., Richard G. \& Moolenbeek R.G. 1995b. Deep-water cones (Gastropoda: Conidae) from the New Caledonia region. In: Bouchet P. (ed.) Résultats des Campagnes Musorstom, Vol. 14: 557-594. Mémoires du Muséum national d'Histoire naturelle 167: Muséum national d'Histoire naturelle, Paris. 
Rolán E. \& Raybaudi-Massilia G. 1994. New investigation on the radular teeth of Conus (Prosobrachia, Conidae). Part II. Argonauta 8 (7-12): 7-68.

Stamatakis A. 2006. RAxML-VI-HPC: maximum likelihood-based phylogenetic analyses with thousands of taxa and mixed models. Bioinformatics 22 (21): 2688-2690. http://dx.doi.org/10.1093/ bioinformatics/btl446

Stamatakis A., Hoover P. \& Rougemont J. 2008. A rapid bootstrap algorithm for the RAxML Web servers. Systematic Biology 57 (5): 758-771. http://dx.doi.org/10.1080/10635150802429642

Taki I. 1937. Zur Morphologie und systematischen Stellung von Conus tuberculosus Tomlin. Zoological Magazine, Japan 49 (6): 218-238.

Tamura K., Dudley J., Nei M. \& Kumar S. 2007. MEGA4: molecular evolutionary genetics analysis (MEGA) software version 4.0. Molecular Biology and Evolution 24: 1596-1599. http://dx.doi. org $/ 10.1093 / \mathrm{molbev} / \mathrm{msm} 092$

Tenorio M.J. 2015a. A new Profundiconus from northern New Caledonia: Profundiconus zardoyai sp. nov. (Gastropoda, Conilithidae). Xenophora Taxonomy 6: 30-38.

Tenorio M.J. 2015b. Notes on Profundiconus smirna (Bartsch \& Rehder, 1943) with description of a new species: Profundiconus smirnoides sp. nov. (Gastropoda, Conilithidae). Xenophora Taxonomy 7: $15-26$.

Tenorio M.J. \& Poppe G.T. 2004. Description of three deep-water species of Conus from the Central Philipines (Gastropoda, Conidae). Visaya 1 (1): 20-30.

Tenorio M.J., Tucker J.K. \& Chaney H.W. 2012. The Families Conilithidae and Conidae - The Conus of the Eastern Pacific. A Conchological Iconography, Vol. 18. Conchbooks, Hackenheim, Germany.

Tucker J.K. \& McLean J.H. 1993. The rediscovery, morphology, and identity of Conus emersoni Hanna, 1963. The Nautilus 107 (1): 29-32.

Tucker J.K. \& Tenorio M.J. 2009. Systematic Classification of Recent and Fossil Conoidean Gastropods, with Keys to the Genera of Cone Shells. ConchBooks, Hackenheim, Germany.

Tucker J.K. \& Tenorio M.J. 2013. Illustrated Catalog of the Living Cone Shells. MdM Shellbooks, Wellington Florida.

Von Martens E. 1901. Einige neue Meer-Conchylien von der deutschen Tiefsee-Expedition. Sitzungsberichte der Gesellschaft Naturforschender Freunde zu Berlin 1901: 14-26. Available from http://biodiversitylibrary.org/page/8798420 [accessed 2 Jan. 2016]

WoRMS Editorial Board. 2015. World Register of Marine Species. Available from http://www. marinespecies.org [accessed 30 Nov. 2015]

Manuscript received: 24 September 2015

Manuscript accepted: 9 December 2015

Published on: 29 January 2016

Topic editor: Rudy Jocqué

Desk editor: Danny Eibye-Jacobsen

Printed versions of all papers are also deposited in the libraries of the institutes that are members of the EJT consortium: Muséum national d'Histoire naturelle, Paris, France; Botanic Garden Meise, Belgium; Royal Museum for Central Africa, Tervuren, Belgium; Natural History Museum, London, United Kingdom; Royal Belgian Institute of Natural Sciences, Brussels, Belgium; Natural History Museum of Denmark, Copenhagen, Denmark. 
Appendix. Measurements of shell parameters (see Material and methods).

\begin{tabular}{|c|c|c|c|c|c|}
\hline Taxon & $\mathbf{S}_{\mathbf{L}}(\mathrm{mm})$ & $\mathbf{A H}(\mathrm{mm})$ & $\mathbf{M D}(\mathrm{mm})$ & HMD (mm) & SH $(\mathrm{mm})$ \\
\hline profundorum & 67.0 & 49.1 & 29.4 & 41.7 & 17.9 \\
\hline profundorum & 73.1 & 58.2 & 31.7 & 47.6 & 14.9 \\
\hline profundorum & 103.9 & 81.5 & 47.4 & 69.0 & 22.4 \\
\hline profundorum & 105.2 & 79.8 & 44.1 & 71.9 & 25.4 \\
\hline profundorum & 108.3 & 83.7 & 46.7 & 71.8 & 24.6 \\
\hline profundorum & 112.0 & 90.2 & 47.8 & 78.8 & 21.8 \\
\hline profundorum & 115.5 & 91.0 & 47.2 & 76.0 & 24.5 \\
\hline profundorum & 129.0 & 103.1 & 55.2 & 82.5 & 25.9 \\
\hline profundorum & 104.0 & 83.3 & 47.4 & 70.7 & 20.7 \\
\hline profundorum & 105.0 & 83.7 & 45.5 & 69.6 & 21.3 \\
\hline profundorum & 111.1 & 87.3 & 52.6 & 75.8 & 23.8 \\
\hline profundorum & 109.4 & 81.3 & 49.3 & 66.4 & 28.1 \\
\hline profundorum & 81.0 & 60.0 & 35.9 & 50.4 & 21.0 \\
\hline profundorum & 110.0 & 84.7 & 47.8 & 73.5 & 25.3 \\
\hline profundorum & 87.0 & 68.2 & 36.0 & 56.5 & 18.8 \\
\hline profundorum & 116.0 & 89.9 & 49.0 & 77.4 & 26.1 \\
\hline profundorum & 77.6 & 58.0 & 34.4 & 49.0 & 19.6 \\
\hline profundorum & 67.0 & 49.2 & 33.0 & 42.0 & 17.8 \\
\hline profundorum & 66.0 & 51.5 & 28.9 & 41.6 & 14.5 \\
\hline profundorum & 66.0 & 53.6 & 29.9 & 44.6 & 12.4 \\
\hline profundorum & 83.0 & 66.0 & 36.6 & 54.6 & 17.0 \\
\hline profundorum & 115.0 & 87.7 & 52.5 & 74.6 & 27.3 \\
\hline profundorum & 106.0 & 81.6 & 51.5 & 70.3 & 24.4 \\
\hline profundorum & 116.0 & 91.2 & 56.7 & 74.8 & 24.8 \\
\hline profundorum & 75.6 & 57.0 & 32.9 & 46.7 & 18.6 \\
\hline profundorum & 110.5 & 88.5 & 47.7 & 73.1 & 22.0 \\
\hline neocaledonicus & 63.5 & 50.6 & 30.3 & 44.8 & 12.9 \\
\hline neocaledonicus & 52.8 & 42.2 & 23.4 & 37.5 & 10.6 \\
\hline neocaledonicus & 34.4 & 26.9 & 15.1 & 24.7 & 7.6 \\
\hline neocaledonicus & 40.8 & 31.8 & 18.9 & 29.3 & 8.9 \\
\hline neocaledonicus & 43.7 & 35.2 & 19.1 & 30.4 & 8.5 \\
\hline neocaledonicus & 55.0 & 43.9 & 26.8 & 38.1 & 11.1 \\
\hline neocaledonicus & 77.6 & 63.4 & 39.2 & 52.0 & 14.2 \\
\hline neocaledonicus & 40.3 & 33.2 & 19.3 & 28.8 & 7.0 \\
\hline neocaledonicus & 46.1 & 38.6 & 22.7 & 33.7 & 7.6 \\
\hline neocaledonicus & 43.7 & 34.8 & 19.8 & 29.4 & 8.8 \\
\hline neocaledonicus & 53.7 & 42.4 & 24.5 & 35.9 & 11.3 \\
\hline neocaledonicus & 54.0 & 43.7 & 25.0 & 37.9 & 10.3 \\
\hline neocaledonicus & 47.3 & 38.4 & 21.8 & 32.5 & 8.8 \\
\hline neocaledonicus & 52.0 & 43.5 & 25.5 & 37.5 & 8.4 \\
\hline
\end{tabular}


Appendix. [continued] Measurements of shell parameters (see Material and methods).

\begin{tabular}{|c|c|c|c|c|c|}
\hline Taxon & $\mathbf{S}_{\mathbf{L}}(\mathrm{mm})$ & $\mathbf{A H}(\mathrm{mm})$ & MD $(\mathrm{mm})$ & HMD (mm) & SH (mm) \\
\hline neocaledonicus & 43.0 & 34.0 & 19.4 & 29.7 & 9.0 \\
\hline neocaledonicus & 81.7 & 65.5 & 43.4 & 54.4 & 16.2 \\
\hline neocaledonicus & 57.9 & 46.3 & 27.5 & 41.1 & 11.6 \\
\hline neocaledonicus & 70.4 & 57.6 & 36.2 & 46.9 & 12.7 \\
\hline neocaledonicus & 55.5 & 44.4 & 26.4 & 37.1 & 11.1 \\
\hline neocaledonicus & 71.8 & 57.2 & 37.0 & 47.4 & 14.6 \\
\hline neocaledonicus & 54.5 & 43.0 & 25.4 & 38.2 & 11.5 \\
\hline neocaledonicus & 92.0 & 68.2 & 42.0 & 58.0 & 23.8 \\
\hline neocaledonicus & 52.6 & 42.1 & 24.7 & 34.7 & 10.5 \\
\hline neocaledonicus & 65.1 & 51.6 & 32.5 & 42.9 & 13.5 \\
\hline neocaledonicus & 67.3 & 53.7 & 33.0 & 45.1 & 13.6 \\
\hline neocaledonicus & 61.5 & 48.5 & 28.7 & 40.7 & 13.0 \\
\hline neocaledonicus & 53.4 & 42.0 & 22.8 & 35.7 & 11.4 \\
\hline neocaledonicus & 65.5 & 54.0 & 35.7 & 45.7 & 11.5 \\
\hline puillandrei & 47.4 & 35.8 & 19.5 & 29.3 & 11.6 \\
\hline puillandrei & 37.2 & 26.2 & 15.1 & 22.9 & 10.9 \\
\hline puillandrei & 34.5 & 25.4 & 15.0 & 21.5 & 9.1 \\
\hline puillandrei & 50.0 & 36.8 & 22.6 & 32.4 & 13.1 \\
\hline puillandrei & 41.8 & 31.0 & 17.5 & 26.9 & 10.8 \\
\hline puillandrei & 38.1 & 29.4 & 16.9 & 25.9 & 8.7 \\
\hline puillandrei & 44.2 & 32.4 & 19.2 & 28.1 & 11.8 \\
\hline puillandrei & 32.0 & 24.8 & 13.2 & 21.3 & 7.3 \\
\hline puillandrei & 29.5 & 22.6 & 13.1 & 18.4 & 6.9 \\
\hline puillandrei & 41.0 & 31.9 & 18.2 & 27.5 & 9.0 \\
\hline puillandrei & 45.0 & 34.5 & 18.8 & 29.9 & 10.5 \\
\hline puillandrei & 36.0 & 28.5 & 16.6 & 24.4 & 7.5 \\
\hline puillandrei & 41.1 & 30.1 & 17.4 & 26.3 & 11.0 \\
\hline smirnoides & 81.5 & 59.2 & 31.0 & 47.9 & 22.3 \\
\hline smirnoides & 97.9 & 62.7 & 35.0 & 50.5 & 35.2 \\
\hline smirnoides & 63.4 & 46.7 & 24.7 & 38.2 & 16.7 \\
\hline smirnoides & 81.4 & 59.6 & 31.9 & 49.4 & 21.8 \\
\hline smirnoides & 75.3 & 55.4 & 29.9 & 46.2 & 19.9 \\
\hline smirnoides & 75.4 & 55.1 & 29.8 & 45.7 & 20.3 \\
\hline smirnoides & 71.8 & 52.0 & 26.3 & 42.2 & 19.8 \\
\hline smirnoides & 52.0 & 38.2 & 19.8 & 30.7 & 13.8 \\
\hline smirnoides & 73.7 & 55.6 & 27.0 & 42.6 & 18.1 \\
\hline smirnoides & 79.7 & 59.9 & 27.4 & 47.1 & 19.8 \\
\hline smirnoides & 76.7 & 55.8 & 29.6 & 45.1 & 20.9 \\
\hline smirnoides & 84.3 & 62.8 & 34.8 & 50.3 & 21.5 \\
\hline
\end{tabular}

